\title{
Ash Features from Ordinary Activity at Stromboli Volcano
}

\author{
Chiara Benedetta Cannata, Rosanna De Rosa, Paola Donato, Jacopo Taddeucci \\ University of Calabria, Cosenza, Italy \\ Email: chiara.cannata@unical.it
}

Received 12 August 2014; revised 7 September 2014; accepted 2 October 2014

Copyright (C) 2014 by authors and Scientific Research Publishing Inc.

This work is licensed under the Creative Commons Attribution International License (CC BY). http://creativecommons.org/licenses/by/4.0/

(c) (i) Open Access

\section{Abstract}

In this work we focus our attention on micro-scale textural observations and chemical analysis of the surface of ash particles erupted from ordinary activity at Stromboli volcano (Aeolian Islands, Italy). Ashes are related to three vent systems: $\mathrm{NE}_{1}, \mathrm{NE}_{2}$ and $\mathrm{SW}$ showing different eruptive styles. Samples were collected during three campaigns: 1-5 September 2008; 20, 22 September 2008 and 18 June 2009, with two different methods: collection on a clean surface downwind and use of remotely controlled, electrically propelled aeromodels, which penetrate directly in the eruptive plume and collect ash samples that are less affected by transport-related sorting processes. A micro-textural approach has been conducted working at step: from preliminary observations under binocular microscope on a medium number of $\mathbf{7 0 0}$ particles, to thin sections and sub-micron investigations, using high resolution instruments. Micro-texture and morphology of ash particles were observed under FE-SEM, at high magnification $(30,000 / 50,000 \times)$ measuring the main shape parameters (area, perimeter, max length, compactness, Feret's diameter, Heywood's diameter and elongation). Ashes are made up by a wide spectrum of fragments whose end-members are represented by two main textural types with different colour, shape, internal textures and vesicularity named "Type a" and "Type b". "Type a" shows great similarities with fragments called "tachilite" while "Type $b$ " fragments are very similar to the named "sideromelane" fragments. Fragments with intermediate textural features are present and named as "Type $a_{1}$ " and "Type $b_{1}$ ", respectively. The relative abundances of each type of fragments greatly vary in samples collected from different groups of vents. Chemical analysis of the external surfaces indicates that all the different grain types underwent alteration phenomena and precipitation of neo-formation minerals on their surfaces. The alteration is dependent from the atmospheric conditions around the vent and not from the type of fragments. During the periods of sampling, ash erupted from individual explosions of different vents, does not show big differences in morphology and chemistry of surface features, but mainly in terms of relative proportion of fragments. "Type b" fragments predominate in the ash erupted from typical strombolian activity whereas "Type a" fragments are ubiquitous. 
Keywords

Ash, Basaltic, Strombolian, Tachylite, Sideromelane, Ordinary Persistent Activity

\section{Introduction}

Understanding the eruptive dynamic of persistent explosive activity of volcanoes is a formidable task. The eruptions involve a vast range of scales, types and property of fragments and are characterized by complex interaction of physical and chemical processes occurring in conduits, vents and in the atmosphere. The shape and nature of ash particles hold clues about the magma fragmentation processes and the stability of volcanic conduit [1]-[3]. Textural features of pyroclastic materials record physical conditions of magmas near the surface or even at the fragmentation level [4] [5] and ascension rates or decompression of magmas through shallow conduit [6][10]. As inherited characters from eruptive processes, changes in the shape and nature of principal constituents of ash reflect modifications or evolutions of eruptive styles and conduit processes, helping in forecasting the changes of ongoing eruptive events. At Mt. Etna, morphological and component analysis of ash, and further comparison of these data with those from other monitoring techniques, demonstrated a clear relationship between ash features and styles of explosive activity [11] [12]. At Stromboli, ash erupted from different vents during just a few hours of activity may show a strong variability in terms of component abundances, degree and type of alteration and crystallinity [12].

Among pyroclastic materials, airborne ash particles from explosion plumes are the suitable candidates in the petrologic continuous monitoring on the activity of volcanoes. In spite of this, when compared to works on coarser clasts, like lapilli or scoriae and pumices, the studies focused on the textural features of ash are less abundant. First studies conducted on ash have been mainly focused on grain-size and componentry type analysis [13]-[15] and on their surface micro-textures under the SEM [1] [2] [16] or morphologies [17]-[22]. Dellino and La Volpe (1996) introduced new methods using particle outline parameters such as elongation, roundness, compactness and rectangularity to define the particle shapes from Monte Pilato-Rocche Rosse (Lipari, Aeolian Islands). The outline parameters are influenced by transportation mechanisms [17] and the effects of these may be misinterpreted as fragmentation features or vice versa. Few works have been focused instead on the comparison between micro-textural features and component modes on ash [23]-[25]. Recently Lautze et al., 2012 proposed a study on textural feature of ash from volcanic activity of Mt. Etna 2006 and the eruptive crisis at Stromboli in 2007. In Italy the INGV (Istituto Nazionale di Geofisica e Vulcanologia) is in charge of monitoring active and quiescent volcanoes. Recently, scientists developed ash collection and analysis tools specifically suitable for eruption monitoring, mainly at Etna and Stromboli volcanoes [11] [26] [27]. Such techniques enable largely automated, relatively quick, and quantitative classification of the morphoscopy and surface chemistry of a large number (hundreds) of ash particles using a SEM equipped with particle analysis software [12] [25] and EDS micro analyses system.

The chemistry of ash particles is very useful in the studies of volcanic plumes, their environmental impact and implications for human health [28] [29]. During eruptions tephra in plumes can scavenged and deposit volatiles including sulphur, halogen and metal species and also aerosol particles [30]. These may then be leached by rainfall, potentially releasing heavy loadings to soils and water bodies, even provoking contamination of pasture, sometimes with serious impacts on livestock. Chemical analysis on ash surface give information not only on the chemical composition of products erupted but also on crystallinity degree and alteration of ash, thus implementing results obtained from component analysis. This method was tested on the 2006 eruption at Mt. Etna and 2007 at Stromboli (see before), showing the efficiency in characterizing and discriminating ash erupted among different eruptive styles in these basaltic volcanoes.

In this paper we investigate textural, morphological and surface-chemical features of ash from ordinary persistent activity at Stromboli volcano using combined data of texture, morphology and composition.

We show a detailed knowledge of type of fragment which are erupted contemporaneously from different vent systems. The micro-textural study has been conducted working at steps: from preliminary observations on a medium number of 700 particles under binocular microscope, to thin sections and sub-micron investigations using high resolution instruments, where we measured shape parameters and the surface chemistry of ash sampled in different time period from two groups of vents with different explosive Strombolian styles. 

2002

Typical Strombolian activity consists of intermittent mild explosions, commonly every 10 - 20 min, throwing scoriaceous bombs, lapilli and ash from ten to hundreds of meters above the craters, and continuous stream of gas, with an estimated output of 6000 - 12,000 ton/day and mainly formed by $\mathrm{H}_{2} \mathrm{O}, \mathrm{CO}_{2}$ and $\mathrm{SO}_{2}$ [31] [32]. This activity, which is called "normal Strombolian activity" or even "ordinary Strombolian activity", is occasionally interrupted by more energetic events or paroxysms lasting from some tens of seconds [33] to several minutes [34] [35] and throwing pumiceous and scoriaceous bombs, lapilli and ash from several hundred meters to a few kilometres above the craters. Occasionally lava flows are erupted, always flowing onto the Sciara del Fuoco depression, a morphological depression resulting from several flank collapses which have affected the NE flank of the volcano over the past 13,000 years [36] [37]. The most voluminous lava effusions, with durations of several months, usually originate from vents opened some hundreds of meters below the craters [38]. The present-day activity takes place on a crater terrace at $750 \mathrm{~m}$ asl located in the upper part of the Sciara del Fuoco and beneath the peak of Pizzo Sopra la Fossa $(918 \mathrm{~m})$. Within the terrace three main groups of vents, NE-SW aligned, are active: the so-called SW, Central and NE craters. On the basis of Forward Looking Infrared Radiometer (FLIR) observations Patrick et al. (2007) classify explosions of normal Strombolian activity as Type 1 (ash-poor) and Type 2 (ash-bearing), the last furtherly subdivided into two groups: Type 2a and 2b. Type 1 eruptions are ballistic-dominated, while Type 2 produces ash plume. Type 2a exhibits a gas thrust style and throws out a large number of ballistics. Instead Type $2 \mathrm{~b}$ shows a buoyant style with convective velocities visible above the crater rim and expels a minor amount of ballistic particles. Type 2a show velocities up to $50 \mathrm{~m} \cdot \mathrm{s}^{-1}$ at the crater rim and decelerates to buoyant velocities $\left(<15 \mathrm{~m} \cdot \mathrm{s}^{-1}\right)$ within $100 \mathrm{~m}$ above the rim; Type $2 \mathrm{~b}$ activities do not show a deceleration phase but maintains constant buoyant velocities between 1.4 and $10.9 \mathrm{~m} \cdot \mathrm{s}^{-1}$. Crater rim velocities of Type 2a and Type 1 activities are closely similar to each other. However Type $2 \mathrm{~b}$ eruptions have lower crater rim velocities and are consistently smaller in size. Furthermore Type 1 and 2a eruptions are very loud, while Type $2 \mathrm{~b}$ eruptions are commonly inaudible [39].

Whereas Plinian eruptions produce fine particles through the disruption of many small bubbles, Strombolian eruptions normally originate from the bursting of a large gas slug in a fluid magma column, where magma is torn into coarse molten particles. The Type 1 eruption style follows the common perception of Strombolian eruptions: an ejection of coarse, incandescent scoria following roughly ballistic trajectories. These initially molten clots have been explained as fragments of the fluid lava forming the slug wall [40] [41]. Type 2 behaviour, in which a fine particle plume dominates, cannot be explained in the same way. Fine fragmentation (i.e. Type 2 activity) is normally a minor component in Strombolian scenarios [40] [42] due to limitations in the underlying eruption mechanism. Fine particles, and resulting ash plumes (i.e. Type 2 activity) have thus been explained in Strombolian scenarios by either (a) rollback and falling of loose material within the crater rim from above or (b) rheological changes to the magma column [39]. Infrasonic pressures indicate that Type 2a and 2b eruptions are caused by varying levels of bubble overpressure [43] [44]. Individual vents at Stromboli maintain Type 1 and Type 2 phases on a timescale of days to weeks, indicating that backfill or rheological changes exhibit cycles on that timescale. Type $2 \mathrm{a}$ and $2 \mathrm{~b}$ eruptions could appear within minutes of each other, because bubble overpressure can vary significantly on that timescale [39]. Explosive activity in 2008 and 2009 reflects the following scenario: Type 1 eruptive style at NE crater sector and Type $2 \mathrm{~b}$ at SW vent; while central craters were characterized only by puffing activity. Ash sampled before the paroxysmal event of December 2002 was collected by Lautze on the month of May and September 2002. In that period from the 18th and 22nd the activity was characterized by an average of 4 ash-rich explosions (Type 1, see [39]) per hour at the NE crater, with a combined total of 1 to 15 explosions per hour at the NE and SW craters [10] and ref. therein. Frequent and scoria-rich explosions distinguished the explosive activity of September/October months. During the collection period on 29/30 September the eruptive activity showed for 3.5 hours moderate to powerful scoria-rich explosions at the SW crater, while weaker and ash-rich explosions at the NE crater sector.

\section{Methods}

\subsection{Ash Sampling}

Ash samples from 2008-2009 eruptive periods were collected during three sampling campaigns: from 1 to 5 September 2008, 20 and 22 September 2008, and 18 June 2009. Two sampling methods have been adopted. A 
first method consists in the collection of ash particles erupted from each vent, on a clean surface of $1.50 \times 80 \mathrm{~cm}$, downwind hand-holded, during ash falling from the plume. The second sampling methodology involves the use of aeromodels [12], strongly useful to sample ash from single explosions. Aeromodels penetrate directly in the eruptive plume and are capable to collect four samples during the same flight. Ash samples collected with this method are less affected by transport-related sorting processes. Aeromodels are remotely controlled, electrically propelled and equipped with an air temperature sensor and a webcam, which allows having a full view of vent erupting morphology. Ash samples from 18 May and 29 September 2002 were collected in aluminum bins placed within $20 \mathrm{~m}$ of the NE crater rim: location A and B; location C for samples of 29 September 2002 (Figure 1). Table 1 shows the sampling methods for each sample.

\subsection{Compositional Modes}

For each ash sample the coarsest fraction (about $>0.5 \mathrm{~mm}$ ) has been manually separated for the determination of the compositional modes. At least 500 points are counted for each sample and assigned to specific petrographic classes following the criteria proposed by [15]. Ash fragments were first distinguished under binocular microscope on the basis of three main criteria: shape, colour and vesicularity. Subsequent observations under optical microscope on thin sections were performed in order to investigate the inner micro-texture of ash particles.

\subsection{Sub-Micron Scale Imaging and Morphoscopic Investigations}

To visualize sub-micron scale morphological features of ash particles we used a JEOL JSM 6500F Field Emission (Schottky-type) Scanning Emission Microscope (FE-SEM). In comparison to conventional SEMs, FESEMs offer, beside a more stable electron source, a smaller beam capable of higher spatial resolution also at lower acceleration voltages. The nominal resolution of the used FE-SEM is of 1.5 and $3 \mathrm{~nm}$ at 15 and $1 \mathrm{kV}$ voltage acceleration, respectively. For our practical application we used magnifications up to $100,000 \times$, where the carbon coating we used started to appear in the images. Quantitative parameters of ash grain morphology were obtained by processing FE-SEM images on each grain. Automatic morphoscopic analysis under FE-SEM

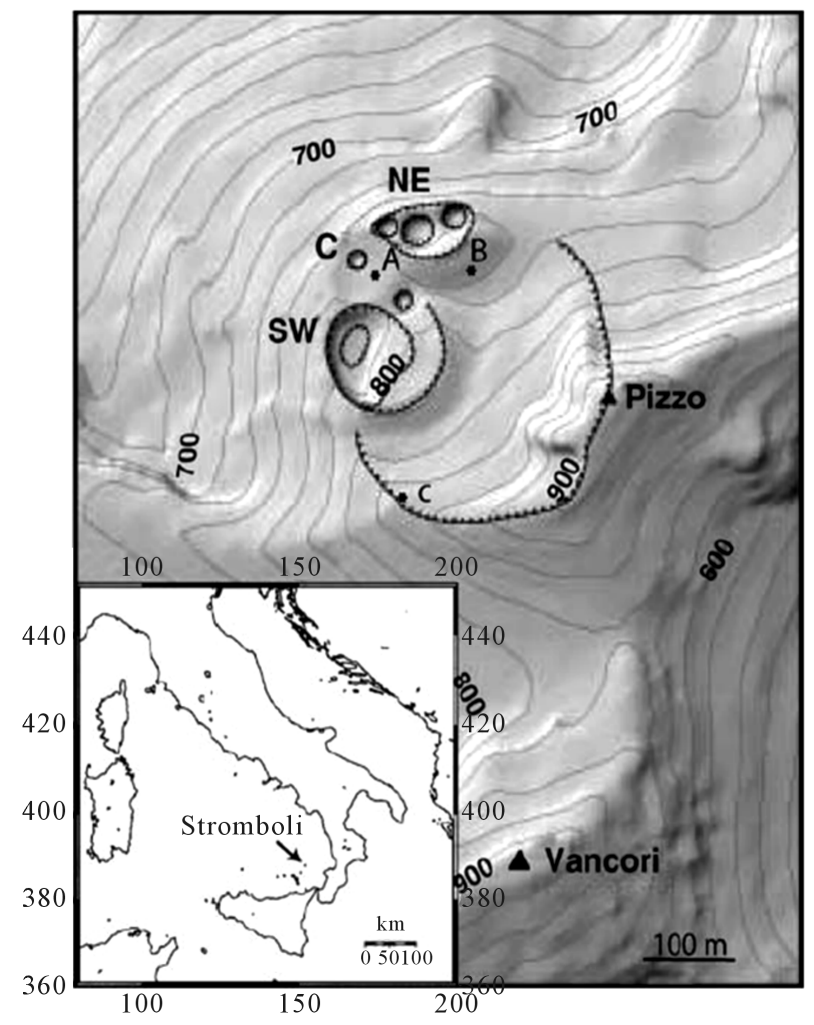

Figure 1. Location of sample collection [10]. 
Table 1. Sampling (September 2008-June 2009-May \& September 2002).

\begin{tabular}{|c|c|c|c|c|c|c|}
\hline Eruption & Date & Time & Vent & $\begin{array}{l}\text { Sample on the } \\
\text { ground }\end{array}$ & $\begin{array}{l}\text { Sample by } \\
\text { aeromodel }\end{array}$ & Eruptive style \\
\hline 1 & 01/09/08 & $11: 30$ & so & b.1, b.1 bis & - & Type 2b \\
\hline 2 & 01/09/08 & $\sim 11.45$ & so & - & $\mathrm{A} 1$ & Type 2b \\
\hline 3 & 01/09/08 & $11: 50$ & SO & - & $\mathrm{A} 2$ & Type 2b \\
\hline 4 & 01/09/08 & 12:05 & SO & - & A3 & Type 2b \\
\hline 5 & 01/09/08 & $12: 12$ & SO & - & A4 & Type 2b \\
\hline 6 & 01/09/08 & $12: 20$ & SO & - & - & Type 2b \\
\hline 7 & 01/09/08 & $12: 32$ & so & - & A5 & Type 2b \\
\hline 8 & 01/09/08 & $12: 58$ & so & b. 2 & - & Type 2a \\
\hline 9 & 01/09/08 & 13:09 & $\mathrm{NE}_{2}$ & - & - & Type 2a \\
\hline 10 & 01/09/08 & $13: 15$ & SO & - & failed & Type 2b \\
\hline 11 & 01/09/08 & $13: 20$ & SO & b.3 & - & Type 2b \\
\hline 12 & 01/09/08 & $13: 36$ & $\mathrm{NE}_{2}$ & - & - & Type 2b \\
\hline 13 & 01/09/08 & $13: 42$ & SO & b.4, b.g. 4 & - & Type 2b \\
\hline 14 & 01/09/08 & $13: 53$ & $\mathrm{NE}_{2}$ & - & - & Type 2b \\
\hline 15 & 01/09/08 & $14: 06$ & so & b.5, b.g.5 & A6 & Type 2b \\
\hline 16 & 01/09/08 & $14: 34$ & SO & b. 6 & A7 & Type 2b \\
\hline 17 & 01/09/08 & $14: 45$ & SO & b.7, b.g.7 & - & Type 2b \\
\hline 18 & 01/09/08 & $14: 50$ & SO & b.8, b.g.8 & - & Type 2b \\
\hline 19 & 01/09/08 & $15: 00$ & SO & b.9, b.g.9 & A8 & Type 2b \\
\hline 20 & 01/09/08 & $15: 04$ & ????? & b.10 & - & Type 2b \\
\hline 21 & 01/09/08 & $15: 20$ & $\mathrm{NE}_{1}$ & - & - & - \\
\hline 22 & 01/09/08 & $15: 35$ & SO & b.11 & - & Type 2b \\
\hline 23 & 01/09/08 & $15: 52$ & $\mathrm{C}$ & - & - & Type 1 \\
\hline 24 & 01/09/08 & $\sim 16: 05$ & $\mathrm{NE}_{1}$ & - & - & Type 2b \\
\hline 25 & 02/09/08 & 09:43 & $\mathrm{NE}_{1}$ & - & - & - \\
\hline 26 & 02/09/08 & 09:56 & $\mathrm{NE}_{1}$ & - & - & - \\
\hline 27 & 02/09/08 & $10: 00$ & $\mathrm{NE}_{2}$ & - & - & - \\
\hline 28 & 02/09/08 & $10: 06$ & SO & b.12 & - & Type 2a \\
\hline 29 & 02/09/08 & $10: 12$ & $\mathrm{NE}_{1}$ & - & A9 & - \\
\hline 30 & 02/09/08 & $10: 15$ & $\mathrm{NE}_{1}$ & - & - & - \\
\hline 31 & 02/09/08 & $10: 17$ & so & b.13 & A10 & Type 2a \\
\hline 32 & 02/09/08 & $10: 30$ & $\mathrm{NE}_{1}$ & - & A11 & Type 1 \\
\hline 33 & 02/09/08 & $10: 36$ & $\mathrm{NE}_{1}$ & - & A12 & Type 1 \\
\hline 34 & 02/09/08 & 10.40 & SO & b.14 & - & Type 2a \\
\hline 35 & 02/09/08 & $10: 56$ & so & - & A13 & Type 1 \\
\hline
\end{tabular}




\section{Continued}

\begin{tabular}{|c|c|c|c|c|c|c|}
\hline 36 & 02/09/08 & 11:02 & $\mathrm{NE}_{2}$ & - & - & - \\
\hline 37 & 02/09/08 & 11:03 & $\mathrm{NE}_{2}$ & - & - & - \\
\hline 38 & 02/09/08 & 11:04 & $\mathrm{NE}_{1}$ & - & A14 & Type 2b \\
\hline 39 & 02/09/08 & $11: 13$ & SO & - & - & Type 1 \\
\hline 40 & 02/09/08 & $11: 19$ & $\mathrm{NE}_{1}$ & - & A15 & Type 1 \\
\hline 41 & 02/09/08 & $\sim 11.40$ & $\mathrm{NE}_{2} ?$ & b.15 & - & Type 1 \\
\hline 42 & 02/09/08 & $11: 50$ & $\mathrm{NE}_{2} ?$ & b.g.16 & - & Type 1 \\
\hline 43 & 02/09/08 & $12: 00$ & SO & b.16, b.g.17 & A16 & Type 1 + Type 2a \\
\hline 44 & 02/09/08 & $12: 10$ & SO & b.18 & - & - \\
\hline 45 & 02/09/08 & 16.30ca & SO?? & s.1 & - & - \\
\hline 46 & 02/09/08 & $16: 51$ & ??? & s.2 & - & - \\
\hline 47 & 04/09/2008 & $10: 30$ & $\mathrm{NE}_{1}$ & - & - & - \\
\hline 48 & 04/09/2008 & $11: 00$ & $\mathrm{NE}_{2}$ & - & - & - \\
\hline 49 & 04/09/2008 & $11: 20$ & $\mathrm{NE}_{2}$ & - & - & - \\
\hline 50 & 04/09/2008 & $11: 36$ & $\mathrm{NE}_{2}$ & - & - & - \\
\hline 51 & 04/09/2008 & $12: 20$ & $\mathrm{NE}_{1}$ & - & - & - \\
\hline 52 & 04/09/2008 & $12: 33$ & $\mathrm{NE}_{1}$ & - & - & Type 1 \\
\hline 53 & 04/09/2008 & $12: 36$ & SO & - & A17 & - \\
\hline 54 & 04/09/2008 & 13:00 & $\mathrm{NE}_{1}$ & - & - & - \\
\hline 55 & 04/09/2008 & 13:07 & $\mathrm{NE}_{1}$ & - & - & - \\
\hline 56 & 04/09/2008 & $13: 30$ & $\mathrm{NE}_{1}$ & - & - & - \\
\hline 57 & 04/09/2008 & 13:38 & SO & - & A18 & - \\
\hline 58 & 04/09/2008 & $13: 54$ & SO & - & A19 & - \\
\hline 59 & 04/09/2008 & 14:06 & SO & - & A20 & - \\
\hline 60 & 04/09/2008 & $14: 27$ & $\mathrm{NE}_{1}$ & - & - & - \\
\hline 61 & 04/09/2008 & $14: 33$ & $\mathrm{NE}_{2}$ & - & A21 & - \\
\hline 62 & 04/09/2008 & $14: 37$ & $\mathrm{C}$ & - & - & - \\
\hline 63 & 04/09/2008 & $14: 37$ & $\mathrm{NE}_{2}$ & - & - & - \\
\hline 64 & 04/09/2008 & $14: 48$ & SO & - & A22 & - \\
\hline 65 & 04/09/2008 & $14: 58$ & SO & - & A23 & - \\
\hline 66 & 04/09/2008 & $15: 29$ & $\mathrm{NE}_{2}$ & - & - & - \\
\hline 67 & 04/09/2008 & $16.10 ? ?$ & $\mathrm{C}$ & b.19, b.g.19 & - & - \\
\hline 68 & 04/09/2008 & $16.20 ?$ & SO & b.20 & - & - \\
\hline 69 & 04/09/2008 & $16: 55$ & $\mathrm{NE}_{2}$ & - & - & - \\
\hline 70 & 04/09/2008 & $17: 14$ & SO & b. 21 & - & - \\
\hline 71 & 04/09/2008 & $17: 19$ & SO & b.22 & - & Type 2b \\
\hline
\end{tabular}




\section{Continued}

\begin{tabular}{|c|c|c|c|c|c|c|}
\hline 72 & 04/09/2008 & $17: 31$ & SO & b. 23 & - & Type 2b \\
\hline 73 & 04/09/2008 & $18: 48$ & SO & b. 24 & - & Type 2b \\
\hline 74 & 05/09/2008 & 09:53 & SO & - & - & Type 2b \\
\hline 75 & 05/09/2008 & $10: 20$ & SO & - & - & Type $2 b$ \\
\hline 76 & 05/09/2008 & $10: 39$ & SO & - & - & - \\
\hline 77 & 05/09/2008 & $10: 45$ & SO & - & - & - \\
\hline 78 & 05/09/2008 & $11: 13$ & SO & - & - & - \\
\hline 79 & 05/09/2008 & $11: 29$ & $\mathrm{C}$ & - & - & - \\
\hline 80 & 05/09/2008 & $11: 51$ & C-SO? & - & - & - \\
\hline 81 & 05/09/2008 & $12: 00$ & $\mathrm{NE}_{1}$ & - & - & - \\
\hline 82 & 05/09/2008 & 12:03 & C-SO? & - & A24 & - \\
\hline 83 & 05/09/2008 & $12: 20$ & $\mathrm{C}$ & - & A25 & - \\
\hline 84 & 20/09/2008 & $16: 47$ & $\mathrm{NE}_{2}$ & 20091647 & - & Type 1 \\
\hline 85 & 20/09/2008 & $17: 02$ & SO & 20091702 & - & Type $2 \mathrm{~b}$ \\
\hline 86 & 20/09/2008 & $17: 42$ & SO & 20091742 & - & Type $2 b$ \\
\hline 87 & 20/09/2008 & $18: 25$ & $\mathrm{NE}_{1}$ & 20091825 & - & Type 1 \\
\hline 88 & 20/09/2008 & $18: 48$ & $\mathrm{NE}_{1}$ & 20091848 & - & Type 1 \\
\hline 89 & $22 / 09 / 2008$ & $15: 46$ & SO? & 22091546 & - & Type 2b \\
\hline 90 & $22 / 09 / 2008$ & $16: 12$ & $\mathrm{NE}_{1}-\mathrm{NE}_{2} ?$ & 22091612 & - & Type 2a \\
\hline 91 & $22 / 09 / 2008$ & $17: 52$ & $\mathrm{NE}_{1}$ & 22091752 & - & Type 1 \\
\hline 92 & $22 / 09 / 2008$ & $18: 18$ & $\mathrm{NE}_{2}$ & 22091818 & - & Type 1 \\
\hline 93 & 22/09/2008 & 18:55 & C-SO? & 22091855 & - & Type $2 \mathrm{~b}$ \\
\hline 94 & 18/06/2009 & 13.30 & SO & 1806091330 & - & \\
\hline 95 & 18/06/2009 & 13.29 & SO & 1806091329 & - & \\
\hline 96 & 18/06/2009 & 13.46 & SO & 1806091346 & - & \\
\hline 97 & 18/06/2009 & 12.39 & $\mathrm{NE}_{2}$ & 1806091239 & - & \\
\hline 98 & 18/06/2009 & 12.34 & $\mathrm{NE}_{2}$ & 1806091234 & - & \\
\hline 99 & 18/06/2009 & 12.59 & $\mathrm{NE}_{2}$ & 1806091259 & - & \\
\hline 100 & 18/06/2009 & 10.40 & $\mathrm{NE}_{2}$ & 1806091040 & - & \\
\hline 101 & 18/06/2009 & 10.48 & $\mathrm{NE}_{1}$ & 1806091048 & - & \\
\hline 102 & 18/06/2009 & 14.01 & $\mathrm{NE}_{2}$ & 1806091401 & - & \\
\hline 103 & $18 / 05 / 2002$ & - & $\mathrm{NE}$ & NS-38 & - & \\
\hline 104 & $18 / 05 / 2002$ & - & SO & NS-35 & - & \\
\hline 105 & $18 / 05 / 2002$ & - & $\mathrm{NE}$ & NS-41 & - & \\
\hline 106 & $18 / 05 / 2002$ & - & SO & NS-47 & - & \\
\hline 107 & 29/09/2002 & - & SO & STR.05 & - & \\
\hline
\end{tabular}


has been performed using the Particle Analyzer tool of the JED 2200 JEOL software package, at INGV (Istituto Nazionale di Geofisica e Vulcanologia) of Rome. The Particle Analyzer software automatically acquires backscattered electron (BSE) images all over the sample, firstly setting the brightness and contrast of the instrument to highlight particle contours against the dark background of the sample holder. Images were acquired at a single magnification (usually 50×), chosen to include the largest number of particles just in only one acquisition and to be enough to measure the smallest particle. On the acquired images the software calculates the area, perimeter, maximum length, rectangularity and circularity on each particle; compactness, Heywood (equivalent) diameter, Feret's (maximum) diameter and elongation. For each sample we analyzed about 500 - 1000 particles. In this work we report results for the parameters of compactness, elongation, and Heywood diameter. Compactness is calculated as the ratio between the particle area and area of the minimum rectangle circumscribed by the particle. The values are in the interval 0 - 1: the closer the shape of an object is to a rectangle, the closer to 1 is the compactness factor. Heywood diameter is calculated from the particle area as the diameter of a circle with the same area. Elongation is the ratio between the length of the longest particle segment and the mean perpendicular intercept. The more elongated is the shape of an object, the higher is its elongation parameter [17].

\subsection{Surface Chemistry}

Under field emission SEM, equipped with a motorized stage, backscattered electron detector and Energy Dispersion System microanalysis, we investigated the overall surface chemistry of ash particles acquiring X-ray spectra from the whole surface of a large number of particles $(>100)$ per sample. The procedure adopted is the following: each particle is circumscribed by a rectangle area, inside of which the instrument acquires a X-ray spectra, than converted into a standardless, quantitative chemical analysis for specified elements. Such "surface analysis" provides a first-order information on the chemical composition of the erupted materials, as well as the degree of alteration of the particles [12] [25]. The results of these automated analyses may serve as a guidance to more advanced, operator-requiring, analyses and also to figure out distinctive features at high magnification and performing spot analysis, both on the fresh surface of the fragment and on the secondary phase minerals lying on particle's surface. The analytical error associated with spectrum quantification is within $10 \%$ of the measured value ( $5 \%$ for oxides with abundances $>10 \%$ mass tot.). The particle roughness and orientation relative to the EDS detector is considered as source of error, as well as particle rotation, which is in the order of $15 \%$ of the measured value [25].

\section{Results}

\subsection{Type of Components}

At basaltic active volcanoes, it is not easy to distinguish juvenile from lithic fragments, therefore in this paper we adopted a criterion without an a priori origin interpretation to distinguish them. Under the binocular and optical microscope fragments were grouped into 6 main petrographic classes on the basis of textural features of fragments: shape, colour, vesicularity and state of alteration:

"Type a" fragments are opaque and brown to black coloured. The grains are poorly or not vesiculated and their shape contours are regular and blocky. Under Field emission SEM Type a fragments appear poorly vesiculated, as found under optical and binocular microscopes, with regular shapes and often almost completely covered by alteration and secondary phase minerals overgrowth over the surface and inside vesicles (Figure 2). In thin section, the groundmass is micro-to crypto-crystalline, with many Fe-Ti oxides; micro-phenocrysts of plagioclase are sometimes present (Figures 3(a)-(c)). Under the binocular they show smooth and shiny surfaces and are sometimes covered by secondary minerals.

“Type b" fragments are transparent, with colours varying from light brown, to yellow, red and brown. They vary from sub-aphyric to porphyric, showing microcrysts and phenocrysts of plagioclase and pyroxene. Fragments are highly vesiculated, with rounded and sometimes elongated bubbles of similar dimensions. Their shape is not regular, and they often show shards morphology (Figure 3(a), Figure 3(b), Figure 3(d), Figure 3(e), Figure 3(f)). Sometimes they show alteration phenomena, but in less abundance than Type a. In the ash of the three periods of sampling we sometimes found microlitic grains of Type b, often with altered rims and/or brown to black patches, and Type a fragments with micro-phenocrysts, shards morphology and large vesicles. Therefore we concluded that among Type a and Type b exists a continuous spectrum of fragments with intermediate 

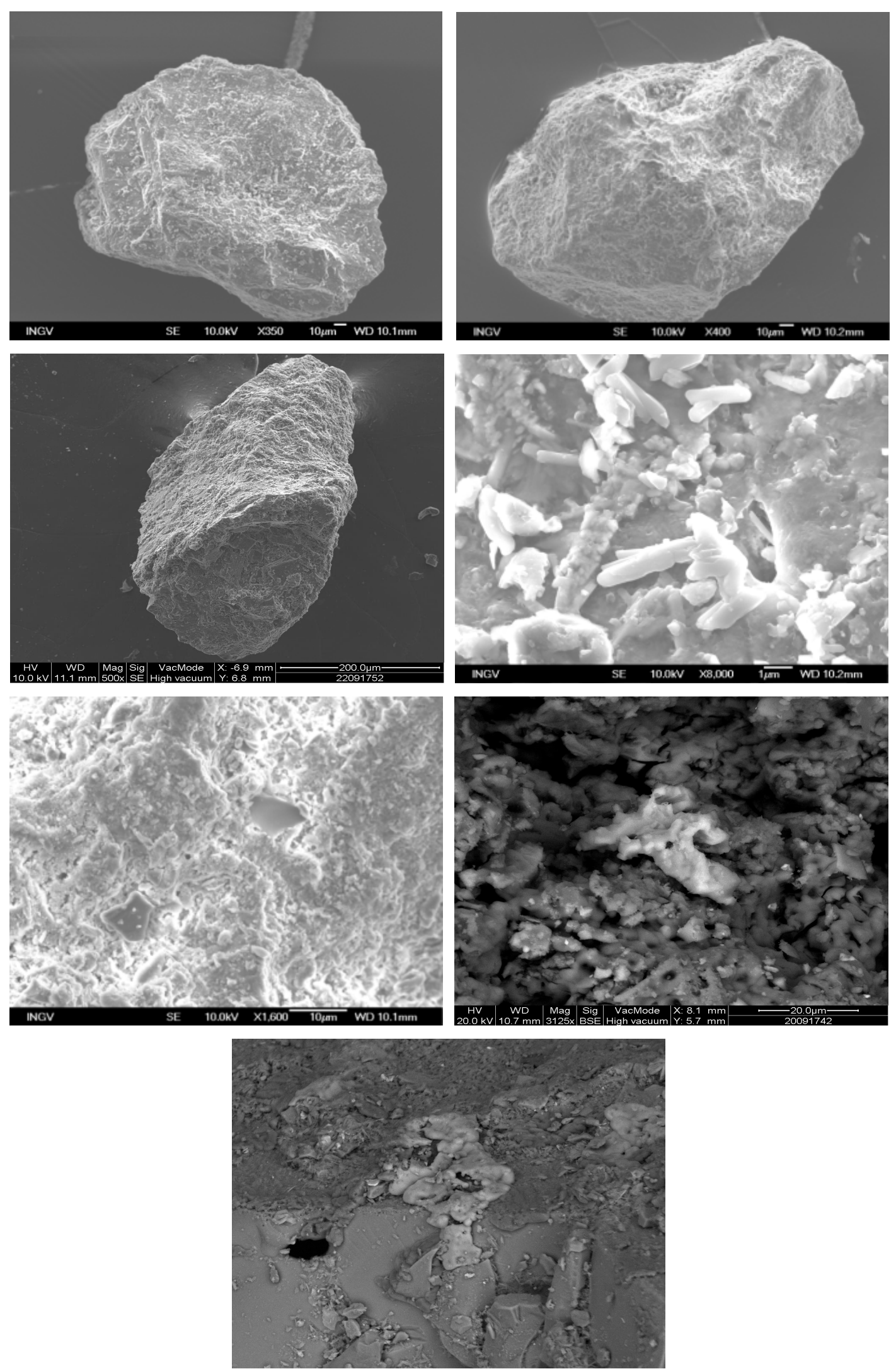

Figure 2. Type a fragments under SEM and surface details.

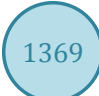




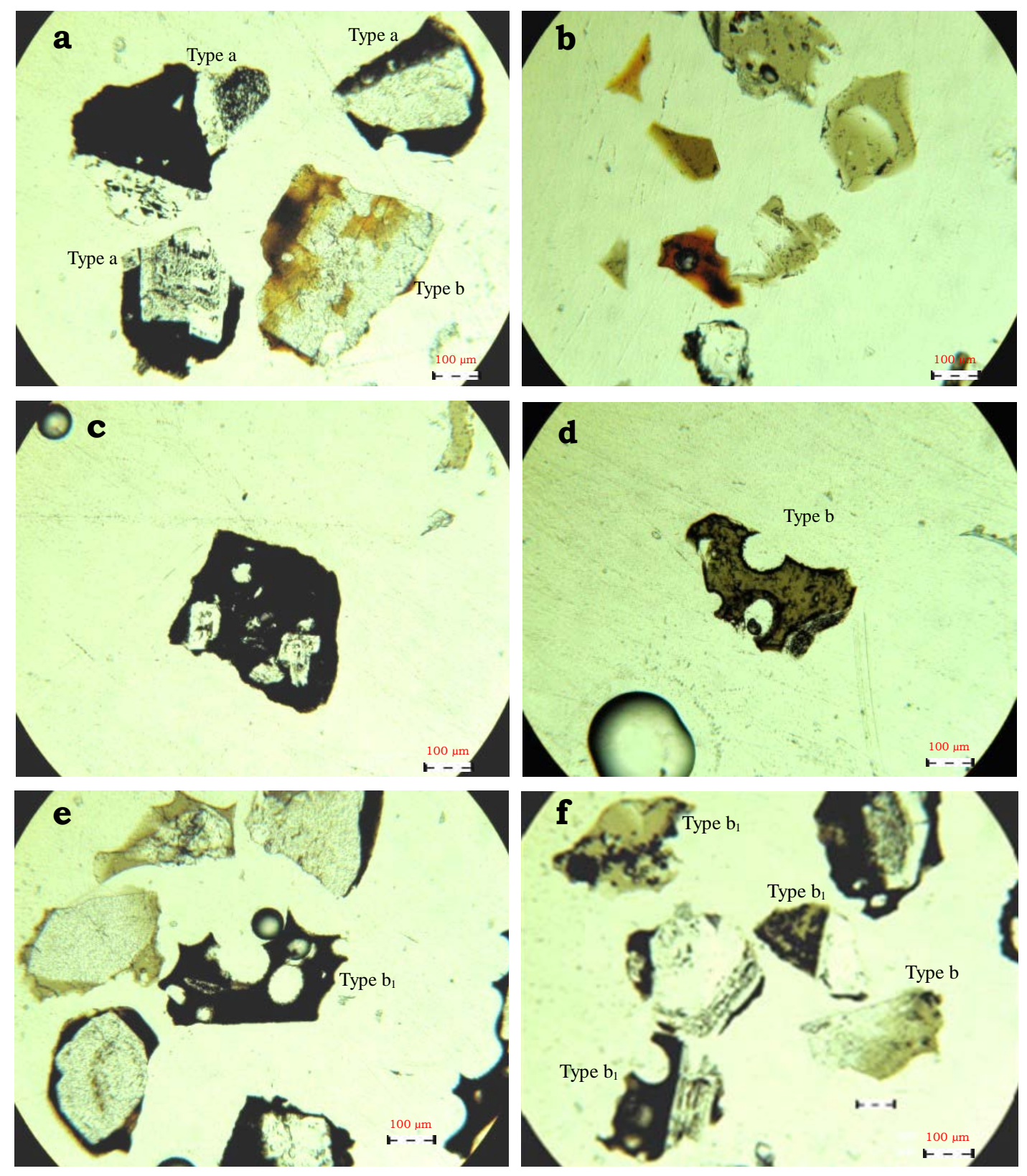

Figure 3. Ash from September 2008: (a) Type a and Type b; (b) Type b; (c) Type a; (d)-(f) Type b and b .

features (Figure 4, Figure 5). Moreover, we adopted other two additional classes: “Type $a_{1}$ " and "Type $b_{1}$ " for fragments having the same shape and vesicularity of Type a and b, but showing different colours and state of alteration. Type $b_{1}$ fragments have the same shape of Type $b$ but more reddish colour and sometimes appear opaque, with altered contour at their rims (Figure 6); Type $\mathrm{a}_{1}$ grains show more angular shapes of Type a and grey colour or red, even in thin section, sometimes being completely covered by secondary alteration phases on their surface. Under SEM Type b appear always highly vesiculated, with fluidal and shards morphology, less interested by alteration phenomenas than Type a, anyway showing overgrowth of secondary minerals (Figure 7). At high magnifications Type $b$ shows smoothly surface. Type $a_{1}$ and Type $b_{1}$ seems to be very close to Type a and $b$ respectively, but Type $a$ is strongly altered, while Type $b_{1}$ shows well-developed neo-formation minerals even of large dimensions.

"Type c" are opaque fragments with reddish colour and always in evident state of alteration. Most of these fragments have micro-crystalline texture, though some of them are porphyric, with phenocrysts of plagioclase 


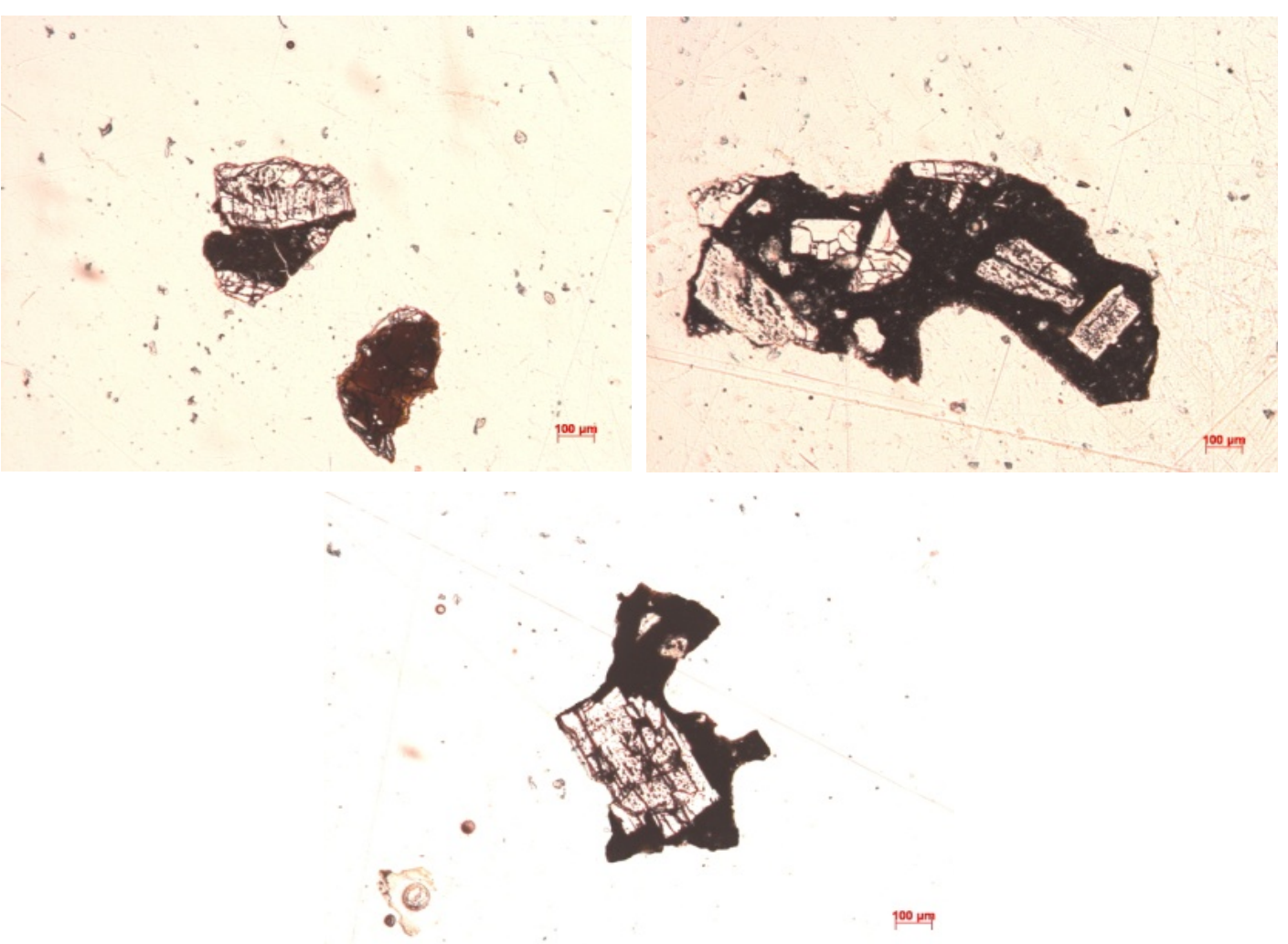

Figure 4. Variations in features of Type a fragments.
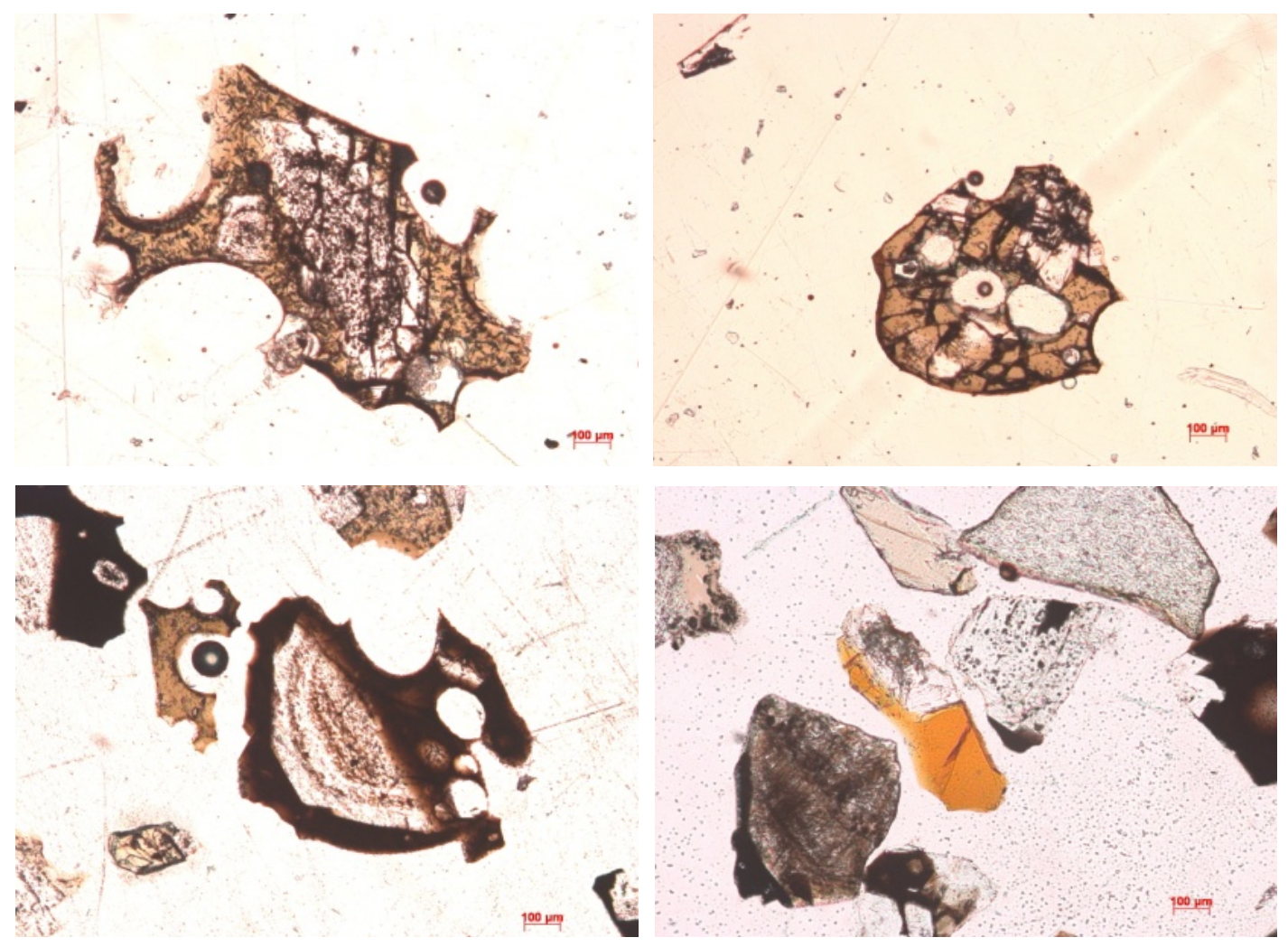

Figure 5. Variations in features of Type b fragments. 

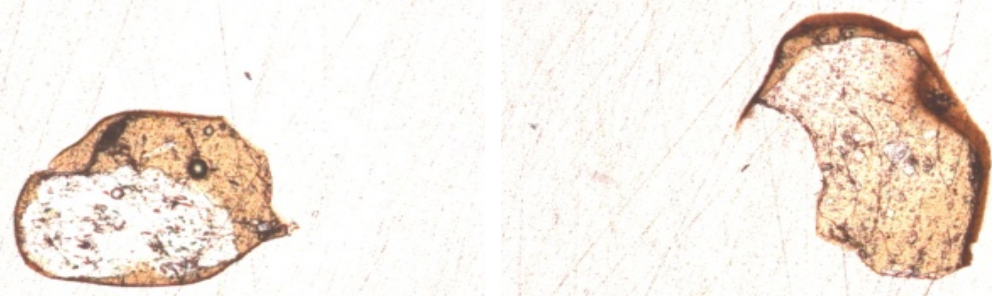

$100 \mathrm{~nm}$

100

Figure 6. Type $b_{1}$ fragments.
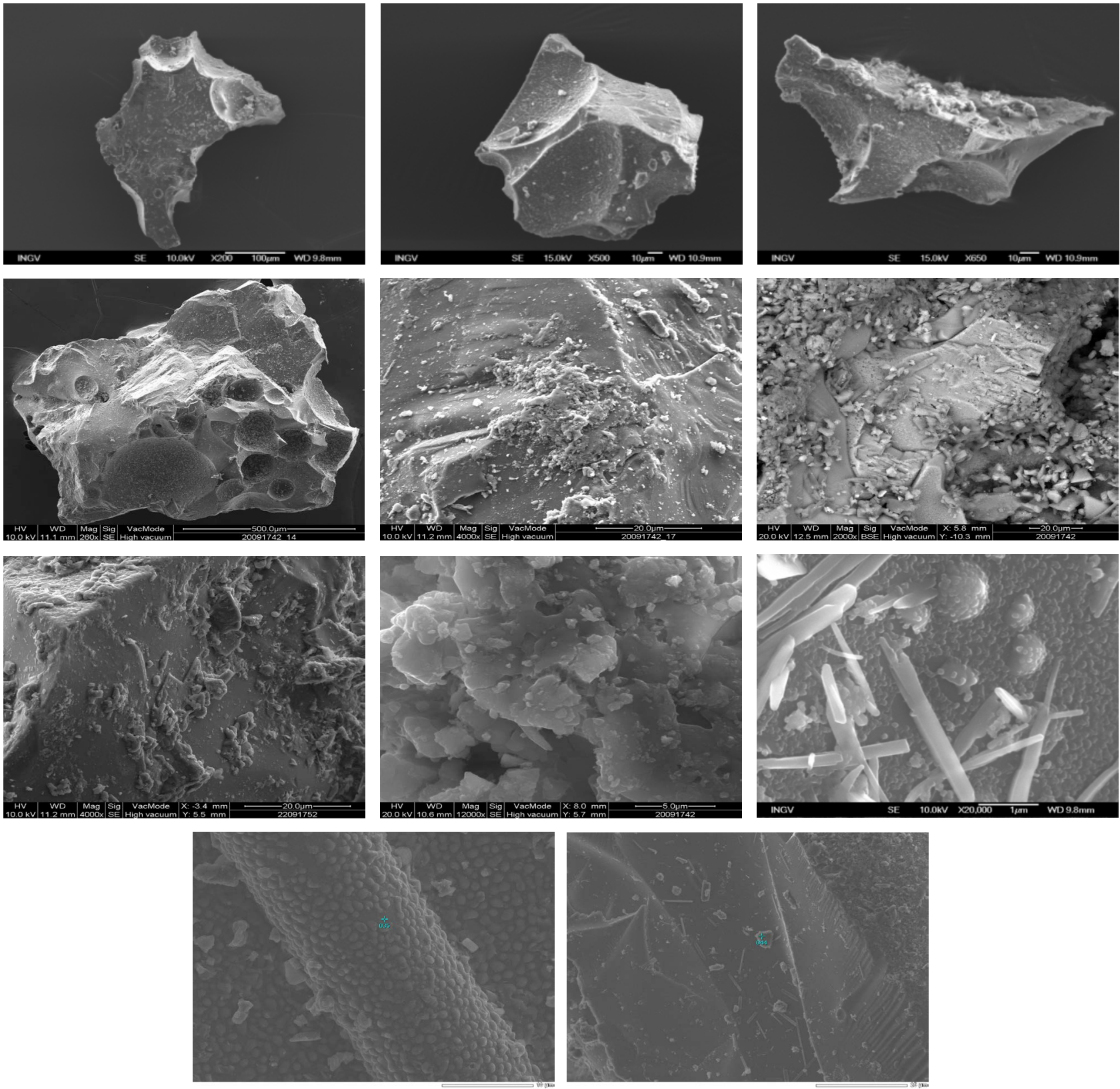

Figure 7. Type b fragments under SEM and surface details. 
and pyroxene and micro-crystalline groundmass. They are poorly or not vesiculated and their shape is always angular (Figure 8).

"Type d" fragments are represented by single crystals of plagioclase, pyroxene and olivine. Plagioclase crystals have variable dimensions, tabular shape, and are often geminated and zoned, with sieve structures; sometimes they show cloudy and altered surfaces (Figure 9). Pyroxenes are green or totally colourless, almost always zoned and geminated and with prismatic shape (Figure 10). Olivines show squat shapes, often interested by fractures and corrosion rims. A few crystals contain melt inclusions (Figure 11).

\subsection{Shape Parameters}

Automated FE-SEM morphoscopic analyses are reported in frequency histograms modified by using the "smoothing" function of KaleidaGraph graphing and data analysis software. Compactness, elongation and Heywood diameter parameters data are presented for all types of particles (Figure 12). Figure shows morphology of ash samples related to the 2008 ordinary activity. Each curve represents the middle point of every rectangle of the underlying histogram and corresponds to a single sample of an explosive episode. Heywood (equivalent) diameter is the most variable parameter among ash fragments. Values of equivalent diameter of particles range between 0 and $1400 \mu \mathrm{m}$ maximum. A wide variability distribution exists for all type of fragments with Type $b$ showing the highest variation. The other two shape parameters are instead more broadly similar for all fragments. In general compactness shows a broadly uniform distribution with sample modes around 0.6. In detail, "Type a" show unimodal platykurtic distribution with only two samples characterized by a bimodal leptokurtic distribution with maximum peaks around 0.6 and 0.7 . Type $b$ show variable distributions; they are mostly bimodal and platykurtic with peaks shifted toward lower values, ranging between 0.4 and 0.6 . Type $a_{1}$ have gaussian distribution with modes around 0.6 ; few samples display a tail toward lower values. Type $b_{1}$ at the contrary have the most broad platykurtic distribution with a peak around 0.3 .

As concerning elongation parameter all samples have modes ranging between 1.5 and 2.5, indicating that particles are more equant than elongate.
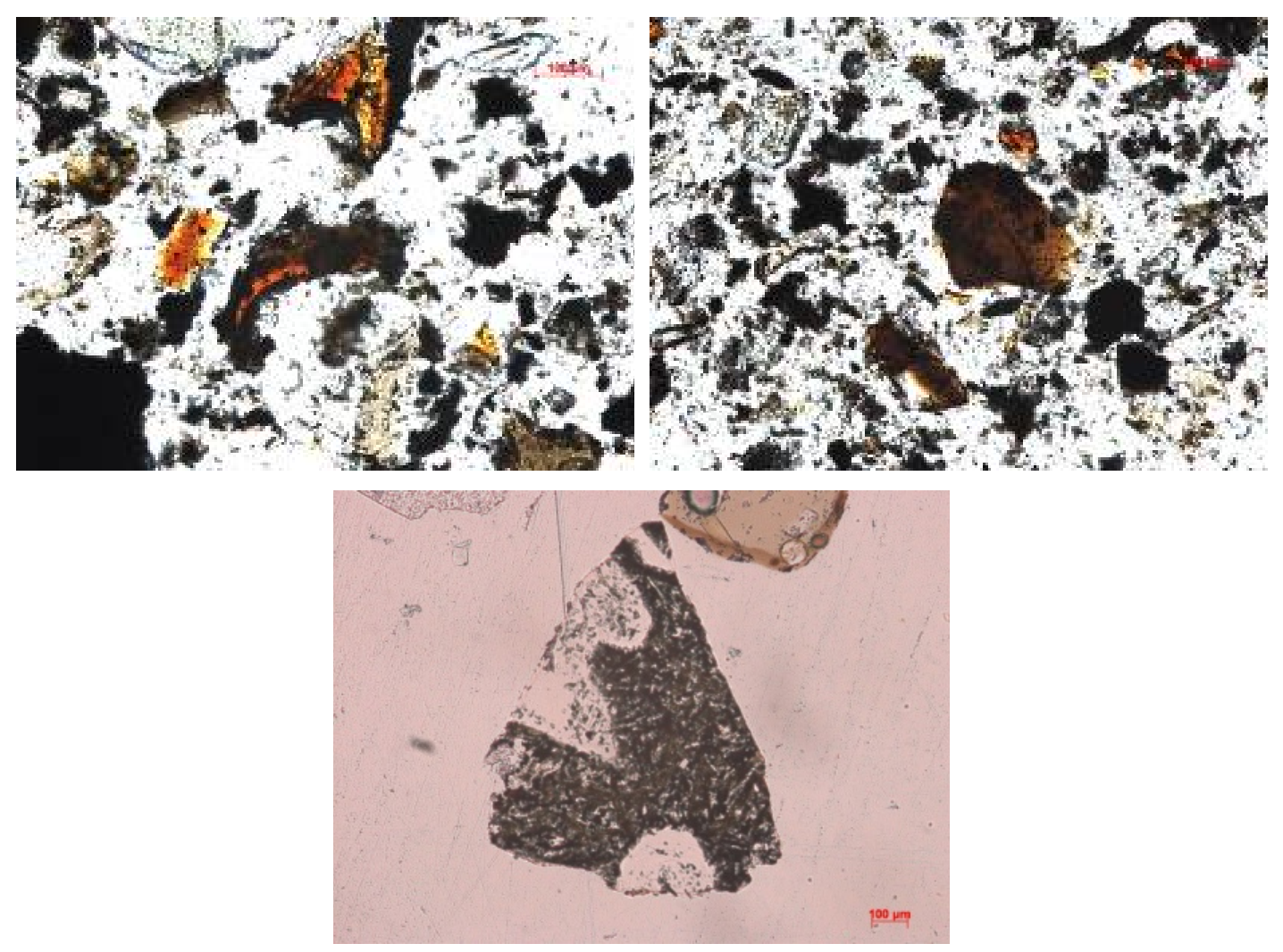

Figure 8. Type c fragments. 

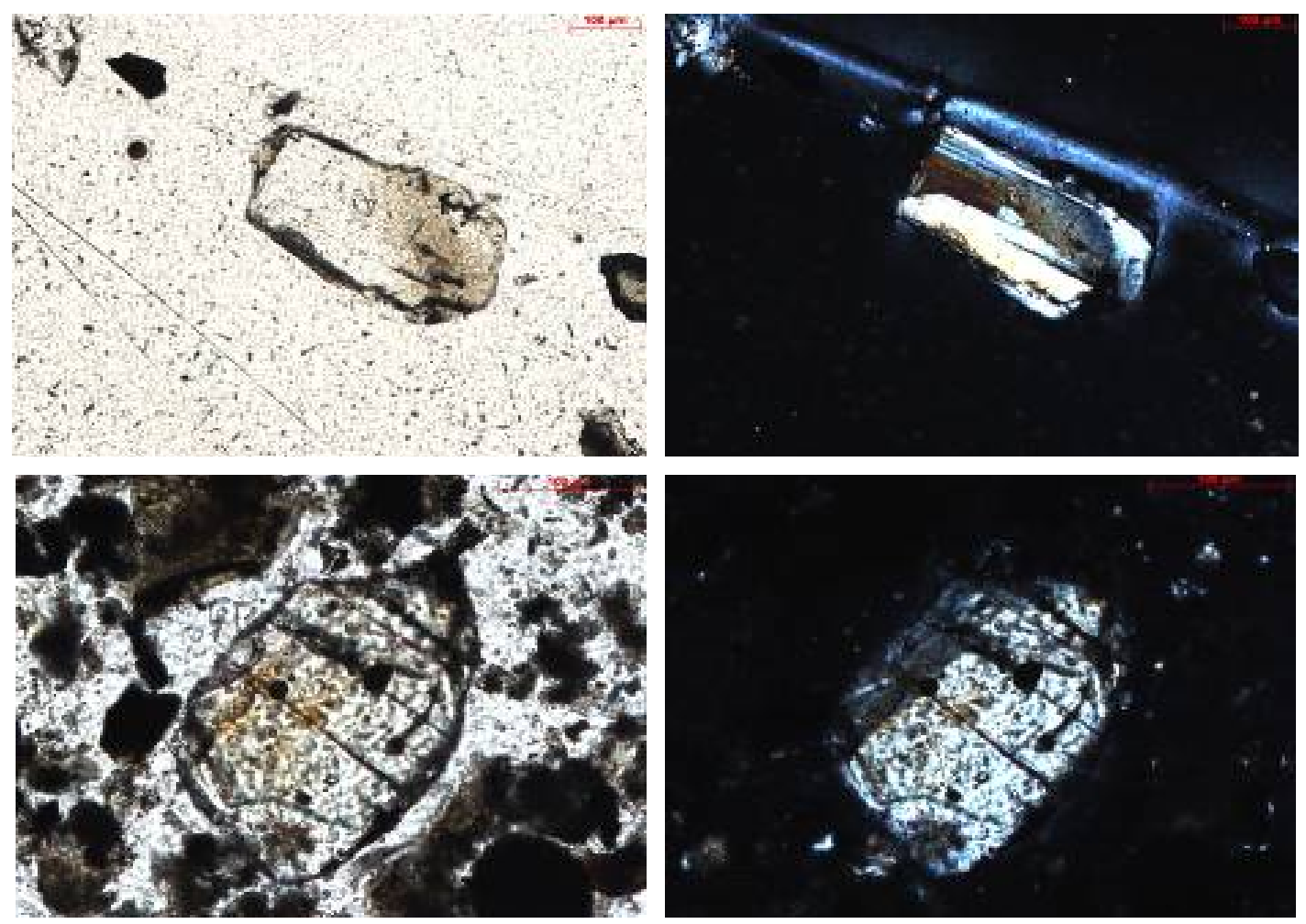

Figure 9. Single crystals of plagioclase.
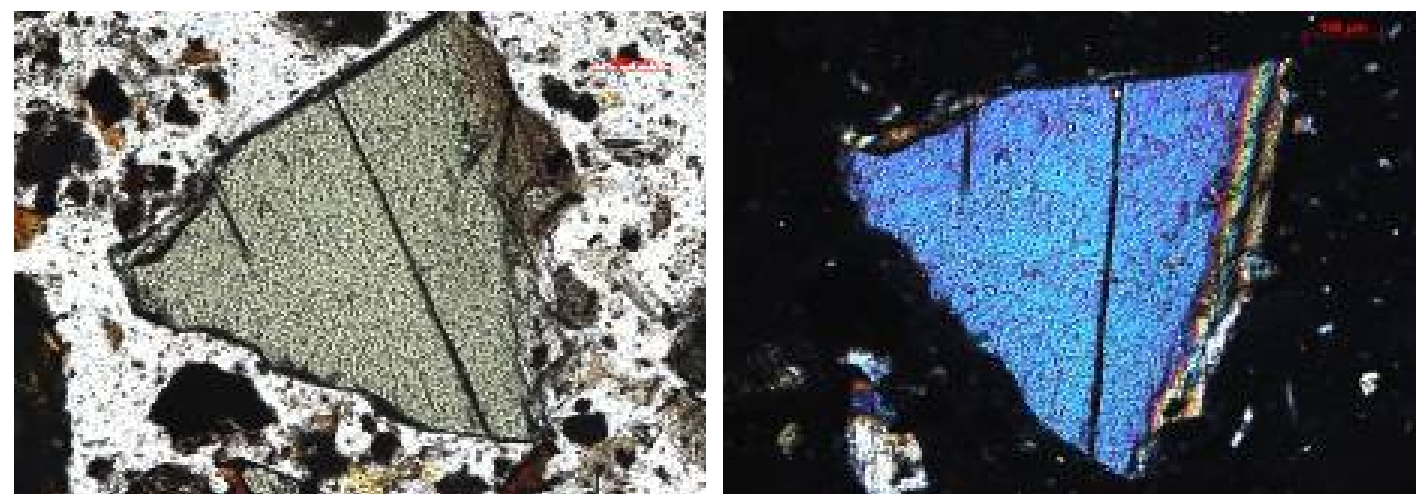

Figure 10. Single crystals of pyroxene.
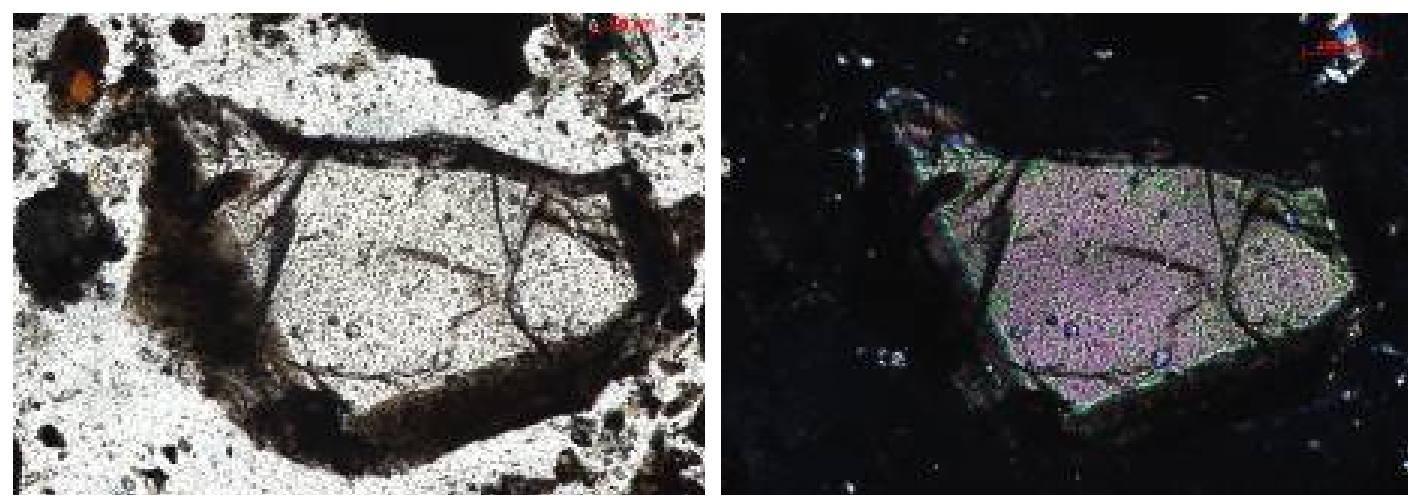

Figure 11. Single crystals of olivine. 

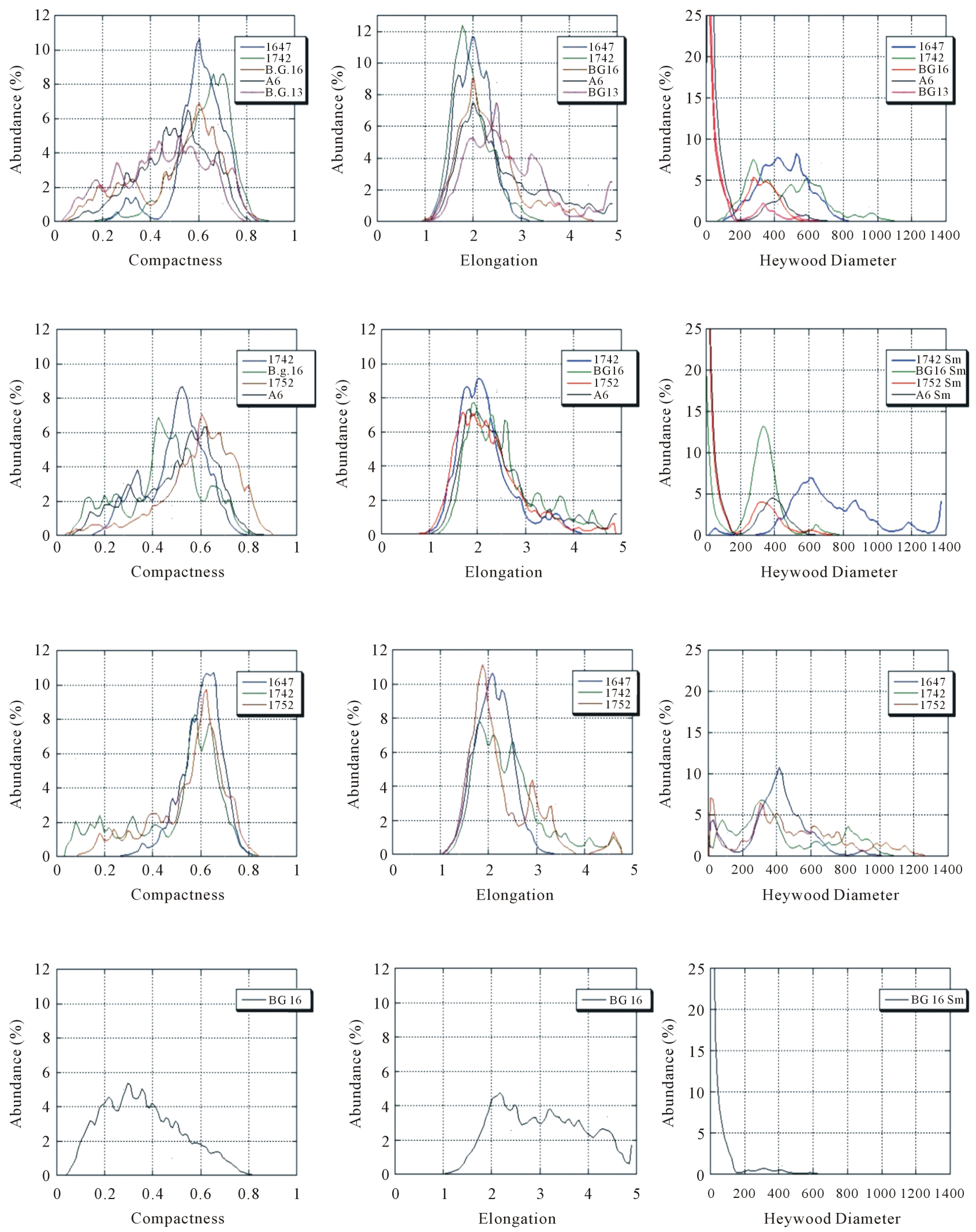

Figure 12. From the top, frequency histograms for fragments: Type a, Type b, Type $a_{1}$ and Type $b_{1}$. 


\subsection{Surface Chemistry}

SEM-EDS micro-analysis on external surfaces of Type $a, b, a_{1}$ and $b_{1}$ shows the presence of secondary phases of $\mathrm{Na}_{2} \mathrm{O}, \mathrm{MgO}$ and $\mathrm{CaO}$ sulphates and halite occurring both as coating and as single crystals. Following the method of Lautze et al. (2012), whole surface EDS data are plotted in ternary diagrams considering $\mathrm{SiO}_{2}, \mathrm{FeO} \mathrm{CaO}$, $\mathrm{Na}_{2} \mathrm{O}, \mathrm{MgO}$ and $\mathrm{Al}_{2} \mathrm{O}_{3}$ together with elements typically related to hydrothermal alteration phenomena as $\mathrm{SO}_{3}$ and $\mathrm{Cl}$. By using this data plotting no differences can be appreciated among ash of different vents or sampled with different procedures. However, ash erupted during humid and cloudy days displays variable amount in those element typical of alteration phenomena. In particular $\mathrm{SO}_{3}$ increases in rainy days (see sample 22091752, Figure 13). By using binary diagrams some differences among ash erupted from different vents are observed. In particular in Figure 14, samples from crater $\mathrm{NE}_{1}$, show higher $\mathrm{Na}_{2} \mathrm{O}, \mathrm{SO}_{3}$ and $\mathrm{CaO}$ content with respect to $\mathrm{NE}_{2}$ despite they were collected with the same sampling method during the same day. This can be related to the different eruptive style of the two crater; $\mathrm{NE}_{1}$ was characterized by gas jet emission with low content of ash particles whereas at $\mathrm{NE}_{2}$ a typical strombolian activity occurred. Considering only samples from $\mathrm{NE}_{2}$, collected with

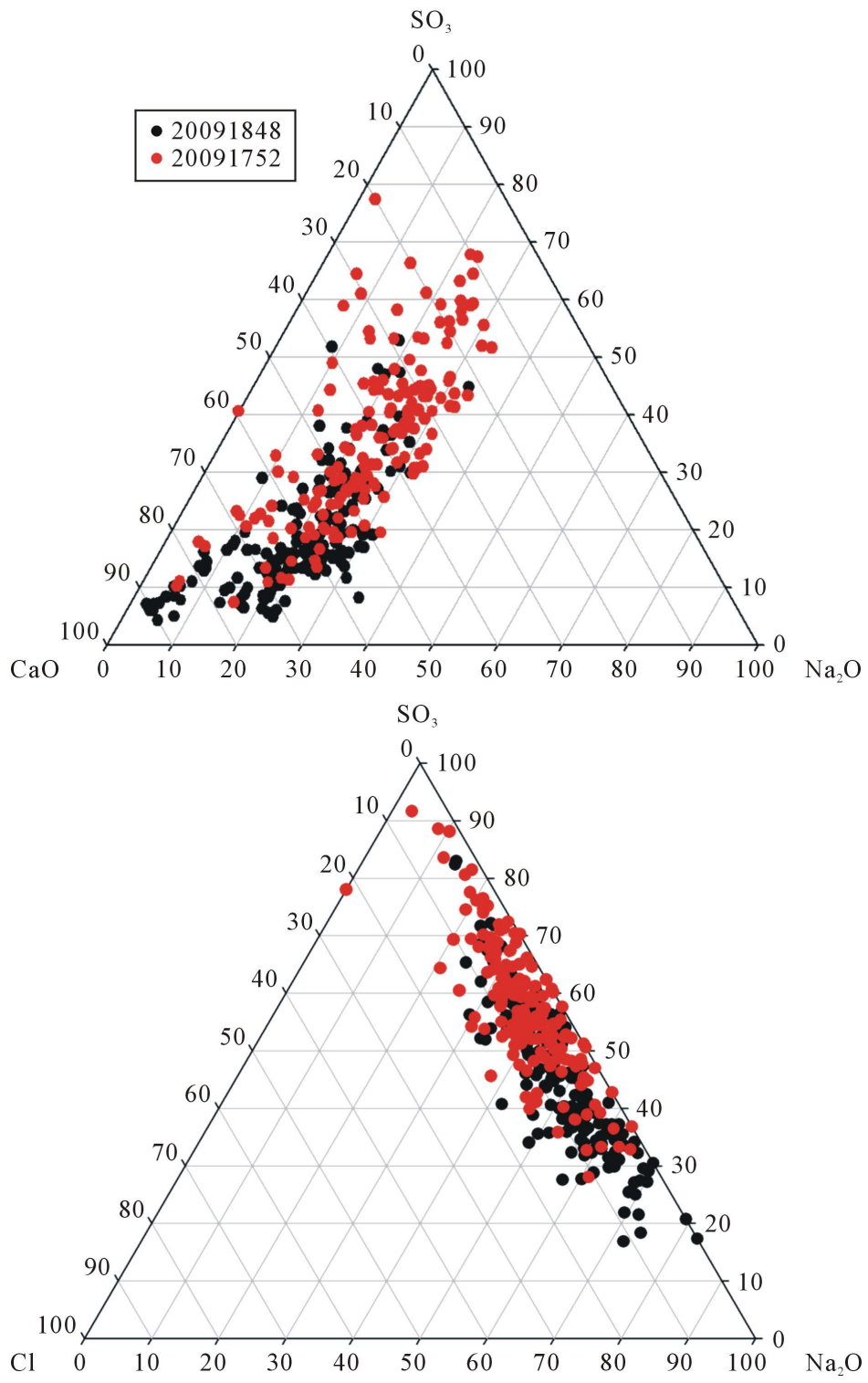

Figure 13. Surface chemistry for ash fragments from $\mathrm{NE}_{1}$ vent erupted during different days (20/09/2008: black dots, 22/09/2008: red dots). 
the same method but in days with different atmospheric conditions, significant differences can be highlighted, with the sample collected during the most humid day (sample 220908) showing higher chlorine content. It is also worth noting that $\mathrm{Cl}, \mathrm{Na}_{2} \mathrm{O}, \mathrm{CaO}$ and $\mathrm{SO}_{3}$ contents reach higher values in samples collected on the ground (Figure 15).

\subsection{Components Distribution}

Figure 16 shows the relative proportions of main components in the coarse-medium ash fraction from ordinary activity of Stromboli during 2002, 2008 and 2009. In the frequency histogram, each bar corresponds to a sample and to a single explosion as well. Results are also grouped on the basis of eruptive vents, from the top of Figure 16: $\mathrm{NE}_{1}, \mathrm{NE}_{2}$ and $\mathrm{SW}$ vents. Modal component analysis revealed that for September 2008 and June 2009 samples, Type $\mathrm{b}$ are dominant in the ash erupted from single explosions of the $\mathrm{NE}_{2}$ vent. The same correspondence is not observed for ash sampled on May and September 2002, for which at the contrary Type b are the dominant fragments in the ash erupted from SW vents. In addition 2002 ash show more variability in component proportions. As for example they show more contents in Type c fragments, which instead remains always low in ash from ordinary activity of September 2008 and June 2009.

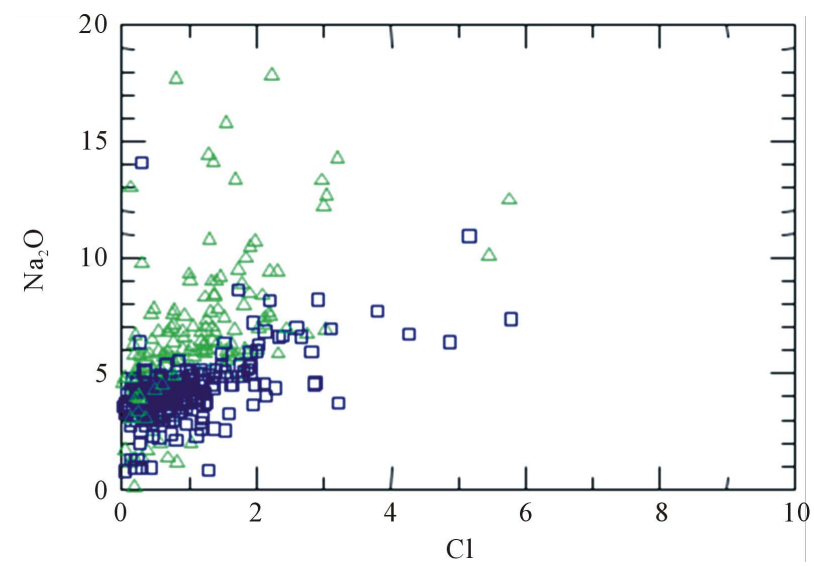

Figure 14. Surface chemistry of ash particles erupted from different vents ( $\mathrm{NE}_{1}$ : green triangles, $\mathrm{NE}_{2}$ : blue square) during the same day $(22 / 09 / 2008)$ and sample with the same method.

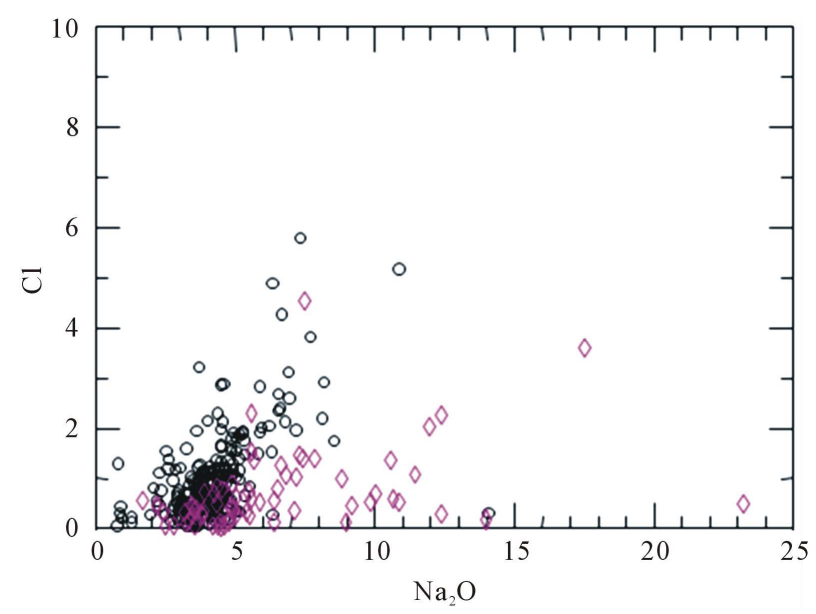

Figure 15. Surface chemistry of ash particles emitted from the same vent $\left(\mathrm{NE}_{2}\right)$ and sampled with the same method but erupted in different days (20/09/2008: violet rhombus, 22/09/ 2008: black circle). 

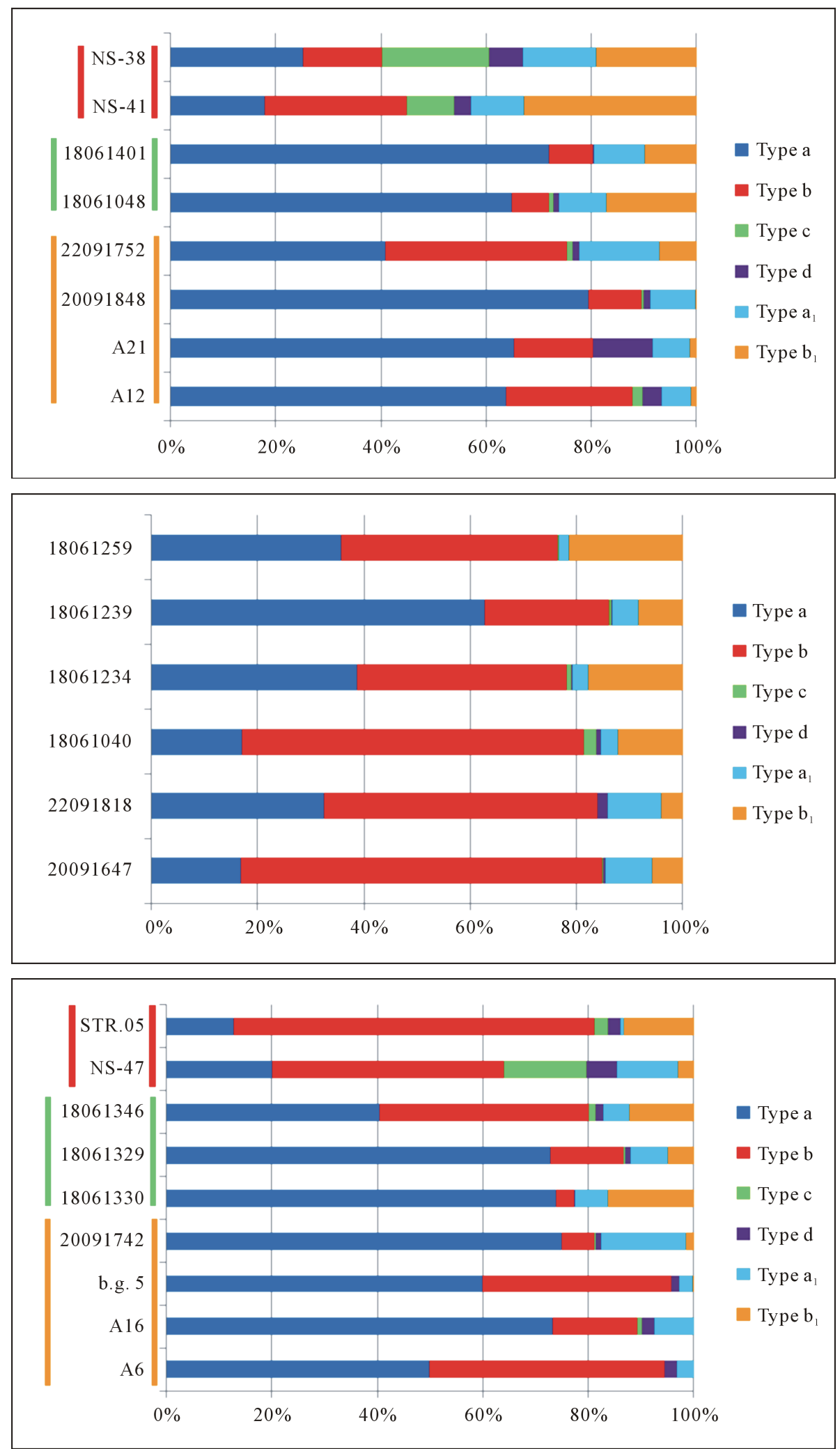

Figure 16. Frequency histograms for classes of ash fragments erupted during September 2008 (held in orange bar), June 2009 (held in green bar) and May-September 2002 (held in red bar). From the top: $\mathrm{NE}_{1}, \mathrm{NE}_{2}$, $\mathrm{SW}$ vents. 


\section{Interpretation and Discussion}

Analyses on ash from single explosions erupted during the ordinary activity at Stromboli volcano on May and September 2002, September 2008 and June 2009 revealed that ash is made up by two main type of ash fragments: one opaque, black, poorly vesiculated, equant in shape and with micro-crystalline groundmass, here called "Type a"; and the other transparent, light brown to dark or yellow, highly vesiculated, with shards morphologies, sub-aphyric groundmass with plagioclase micro- and phenocrysts: "Type b". According to the common nomenclature of basaltic ash, Type a and b correspond to tachylite and sideromelane respectively [1] [11] [44] [45]. A continuous spectrum of fragments with intermediate features between tachylite and sideromelane occurs. Altered fragments are common and named "Type $\mathrm{a}_{1}$ " (altered tachylite fragments) and "Type $\mathrm{b}_{1}$ " (crystalline sideromelane clasts with red, altered rims). Single crystals of plagioclase, pyroxene and olivine are also found ("Type d") together with few cognate lithic particles ("Type c").

The relative abundances of fragment types significantly vary for the groups of vents active during the sampling period. In particular during explosive activity of 2008 and 2009, the $\mathrm{NE}_{2}$ erupted more sideromelane than tachylite ashes. On the contrary, during the activity of May and September 2002 sideromelane fragments predominated at SW vents. During 2008-2009 $\mathrm{NE}_{2}$ was the only vent showing a classic strombolian fountaining activity, while SW produced ash-rich plumes and $\mathrm{NE}_{1}$ was characterized by gas jet emissions, more similar to hornitos than to lava fountains. In 2002 the activity was completely reversed with SW crater producing strombolian fountains, while NE vents gave origin to ash-plumes [10]. Therefore, sideromelane is the main vitric component of ash produced during strombolian eruptions as they are commonly perceived: ejection of coarse, incandescent scoria following ballistic trajectories [39]. On the contrary, tachylite predominates in the ash emitted from ashrich plume eruptions, in which magma ponds nearly the surface relatively longer than in strombolian eruptions, and where a lot of fine ash is produced by the backfilling of loose material from above (recycled fragments). In this scenario magma looses gas and becomes poorly vesiculated, improving its crystallinity (tachylite). In classic strombolian eruption, fountains erupt gas together with magma fragments ponding for relatively short time near the vent, avoiding gas loss and crystal growth.

As revealed by morphoscopic analysis under SEM, sideromelane is the most irregular in shape among ash fragments, with variable but relatively lower compactness values, as well as grain-size (Heywood's diameter). All sideromelane particles show similar, high elongation values, whereas tachylite fragments are more regular and assume different shapes (square, rectangle or other blocky shapes). The observed different shape textures can be interpreted as a consequence of the different rheological properties, in their turn related to their different cooling histories. This supports the model proposed by [46], suggesting that sideromelane formed by fragmentation of the central, microlite-poor, still vesicular, and hotter zone of magma flow, whereas tachylite derives from the fragmentation of the microlite-rich, denser, and cooler magma formed by vesicle escape in the peripheral zone of the magma flux.

On the whole, a correlation exists between alteration degree of all fragments and explosive style of the active crater: fragments erupted during typical strombolian activity are less altered in respect to those related to gas jet emissions, where the gas/particles ratio is higher. Moreover, a high variability is also observed in type and amount of neo-mineral phase for ash particles erupted in different days; in particular it was observed that richer in $\mathrm{SO}_{3}$ are those sampled in cloudy and windy days with high humidity levels, indicating that the alteration process is influenced by the atmospheric boundary conditions. A key factor for the absorption of volatile gas species on ash surface is the humidity of the air promoting the formation of a water film on the ashes which may facilitate the absorption of volatile species [30].

\section{Conclusions}

The work provides a broad knowledge about ash component erupted from ordinary activity at Stromboli and inferences on their formation. Collection of single eruptive pulses allowed to link the ash componentry and features of ash particles to eruptive style. For this purpose we use the innovative and pioneering technique of the collection through the remote-controlled aeromodels which penetrate directly in the plume and sampling only ash erupted from the single pulse active at the time of observation. The correlation of style of explosion and ash componentry help us to infer ideas about the origin of ash particles within the last part of the upper conduit.

Component analyses of ash erupted during ordinary activity at Stromboli volcano revealed the presence of two main categories of fragments ("Type a" or tachylite and "Type b" or sideromelane), single crystals and 
lithics. Tachylite fragments are opaque, black, without vesicles and with micro-crystalline groundmass, while sideromelane is transparent, from lightly to dark brown in colours, highly vesiculated and with sub-aphyric groundmass. Tachylite and sideromelane are the two end-member of a wide spectrum of glassy fragments. They both derive from the same magma slug, but from different sides of the conduit, with sideromelane representing the hotter, central part of the slug. Component analysis revealed that sideromelane clasts (Type b) predominate in the ash erupted from classic Strombolian fountains. This confirms that sideromelane ash originates from rising magma slugs transporting magma at relatively high velocity, without long residence time which remains hot and microlite-poor. At the contrary tachylite prevails in ash-rich plume explosions where backfilling of the conduit occur for the slumping of the inner crater walls or rollback of explosion ejecta down the crater and where magma undergoes rheological changes due of increasing of velocity [39] and ref. therein. Morphoscopic and chemical analysis showed that ash fragments have different morphologies and are subject to alteration phenomena and precipitation of neo-formation minerals on their surface. Ash alteration at Stromboli depends on type of fragment, climatic boundary conditions and eruptive style. This study points out that, unlike other basaltic volcanoes as for example Etna, during ordinary activity at Stromboli, exists a large variability in terms of textural features of ash particles. We suggest that this is linked to the open-conduit system which characterizes the present activity of Stromboli volcano, promoting a wide spectrum of thermo-chemical boundary conditions both for cooling process of magma and hydrothermal alteration of ash fragments near the vent. Future works will be directed to experimental studies on the nature of tachylite and sideromelane in terms of viscosity of melts. Furthermore correlation between eruptive style, nature of ash product and jet heigh and velocities will reinforce our work and improve our knowledge about the ordinary activity at Stromboli volcano.

\section{References}

[1] Heiken, G. and Wohletz, K.H. (1985) Volcanic Ash. University of California Press, Berkeley, 245 p.

[2] Sheridan, M.F. and Marshall, J.R. (1983) Interpretation of Pyroclast Surface Features Using SEM Images. Journal of Volcanology and Geothermal Research, 16, 153-159. http://dx.doi.org/10.1016/0377-0273(83)90088-4

[3] Palladino, D.M. and Taddeucci, J. (1998) The Basal Ash Deposit of the Sovana Eruption (Vulsini Volcanoes, Central Italy): The Product of a Dilute Pyroclastic Density Current. Journal of Volcanology and Geothermal Research, 87, 233-254. http://dx.doi.org/10.1016/S0377-0273(98)00095-X

[4] Mangan, M.T., Cashman, K.V. and Newman, S. (1993) Vesiculation of Basaltic Magma during Eruption. Geology, 21, 157-160. http://dx.doi.org/10.1130/0091-7613(1993)021<0157:VOBMDE>2.3.CO;2

[5] Cashman, K.V. and Mangan, M.T. (1994) Physical Aspects of Magmatic Degassing II. Constraints on Vesiculation Processes from Textural Studies of Eruptive Products. In: Carroll, M.R. and Holloway, J.R., Eds., Volatiles in Magmas, Mineralogical Society of America, Chantilly, 447-478.

[6] Hammer, J.E., Cashman, K.V., Hoblitt, R.P. and Newman, S. (1999) Degassing and Microlite Crystallization during the Pre-Climatic Events of the 1991 Eruption of Mt. Pinatubo, Philippines. Bulletin of Volcanology, 60, 355-380. http://dx.doi.org/10.1007/s004450050238

[7] Polacci, M., Pioli, L. and Rosi, M. (2003) The Plinian Phase of the Campanian Ignimbrite Eruption (Phlegrean Fields, Italy): Evidence from Density Measurements and Textural Characterization of Pumice. Bulletin of Volcanology, 65, 418-432. http://dx.doi.org/10.1007/s00445-002-0268-4

[8] Houghton, B.F., Wilson, C.J.N., Del Carlo, P., Coltelli, M., Sable, J.E. and Carey, R.J. (2004) The Influence of Conduit Processes on Changes in Style of Basaltic Plinian Eruptions: Tarawera 1886 and Etna 122 BC. Journal of Volcanology and Geothermal Research, 137, 1-14. http://dx.doi.org/10.1016/j.jvolgeores.2004.05.009

[9] Gurioli, L., Houghton, B., Cashman, K. and Cioni, R. (2004) Complex Changes in Eruption Dynamics during the 79 AD Eruption of Vesuvius. Bulletin of Volcanology, 67, 144-159. http://dx.doi.org/10.1007/s00445-004-0368-4

[10] Lautze, N.C. and Houghton, B.F. (2007) Linking Variable Explosion Style and Magma Textures during 2002 at Stromboli Volcano, Italy. Bulletin of Volcanology, 69, 445-460. http://dx.doi.org/10.1007/s00445-006-0086-1

[11] Taddeucci, J., Pompilio, M. and Scarlato, P. (2002) Monitoring the Explosive Activity of the July-August 2001 Eruption of Mt. Etna (Italy) by Ash Characterization. Geophysical Research Letters, 29, 1-4.

[12] Taddeucci, J., Scarlato, P.G., Andronico, D., Cristaldi, A., Büttner, R., Zimanowsky, B. and Küppers, U. (2007) Advances in the Study of Volcanic Ash. Eos, 88, 253-260. http://dx.doi.org/10.1029/2007EO240001

[13] Cas, R.A.F. and Wright, J.V. (1987) Volcanic Successions: Modern and Ancient. Allen and Unwin, London. http://dx.doi.org/10.1007/978-94-009-3167-1

[14] Fisher, R.V. and Schmincke, H.U. (1984) Pyroclastic Rocks. Springer Berlin Heidelberg, New York. 
http://dx.doi.org/10.1007/978-3-642-74864-6

[15] De Rosa, R. (1999) Compositional Modes in the Ash Fraction of Some Modern Pyroclastic Deposits: Their Determination and Significance. Bulletin of Volcanology, 61, 162-173. http://dx.doi.org/10.1007/s004450050269

[16] Wohletz, K.H. (1986) Explosive Magma-Water Interactions: Thermodynamics, Explosion Mechanisms and Field Studies. Bulletin of Volcanology, 48, 245-264.

[17] Dellino, P. and La Volpe, L. (1996) Image Processing Analysis in Reconstructing Fragmentation and Transportation Mechanisms of Pyroclastic Deposits. The Case of Monte Pilato-Rocche Rosse Eruptions, Lipari (Aeolian Islands, Italy). Journal of Volcanology and Geothermal Research, 71, 13-29. http://dx.doi.org/10.1016/0377-0273(95)00062-3

[18] Dellino, P. and Liotino, G. (2002) The Fractal and Multifractal Dimension of Volcanic Ash Particles Contour: A Test Study on the Utility and Volcanological Relevance. Journal of Volcanology and Geothermal Research, 113, 1-18. http://dx.doi.org/10.1016/S0377-0273(01)00247-5

[19] Maria, A. and Carey, S. (2002) Using Fractal Analysis to Quantitatively Characterize the Shape of Volcanic Particles. Journal of Geophysical Research, 107, ECV 7-1-ECV 7-17. http://dx.doi.org/10.1029/2001JB000822

[20] Riley, C.M., Rose, W.I. and Bluth, G.J.S. (2003) Quantitative Shape Measurements of Distal Volcanic Ash. Journal of Geophysical Research, 108, 2504.

[21] Ersoy, O., Gourgaud, A., Aydar, E., Chinga, G. and Thouret, J.-C. (2007) Quantitative Scanning-Electron Microscope Analysis of Volcanic Ash Surfaces: Application to the 1982-1983 Galunggung Eruption (Indonesia). Geological Society of America Bulletin, 119, 743-752. http://dx.doi.org/10.1130/B26048.1

[22] Ersoy, O. (2010) Surface Area and Volume Measurements of Volcanic Ash Particles by SEM Stereoscopic Imaging. Journal of Volcanology and Geothermal Research, 190, 290-296. http://dx.doi.org/10.1016/j.jvolgeores.2009.12.006

[23] De Rosa, R. and Sheridan, M.F. (1983) Evidence for Magma Mixing in the Surge Deposits of the Mt. Guardia Sequence, Lipari. Journal of Volcanology and Geothermal Research, 17, 313-328. http://dx.doi.org/10.1016/0377-0273(83)90074-4

[24] Cioni, R., D’Oriano, C. and Bertagnini, A. (2008) Fingerprinting Ash Deposits of Small Scale Eruptions by Their Physical and Textural Features. Journal of Volcanology and Geothermal Research, 177, 277-287. http://dx.doi.org/10.1016/j.jvolgeores.2008.06.003

[25] Lautze, N., Taddeucci, J., Andronico, D., Cannata, C., Tornetta, L., Scarlato, P., Houghton, B. and Lo Castro, M.D. (2012) SEM-Based Methods for the Analysis of Basaltic Ash Applied from Weak Explosive Activity at Etna in 2006 and the 2007 Eruptive Crisis at Stromboli. Physics and Chemistry of the Earth, 45-46, 113-127. http://dx.doi.org/10.1016/j.pce.2011.02.001

[26] Andronico, D., Scollo, S., Cristaldi, A. and Caruso, S. (2008) The 2002-2003 Etna Explosive Activity: Tephra Dispersal and Features of the Deposit. Journal of Geophysical Research, 113, Article ID: B04209. http://dx.doi.org/10.1029/2007JB005126

[27] Cimarelli, C., Di Traglia, F. and Taddeucci, J. (2010) Basaltic Scoria Textures from a Zoned Conduit as Precursors to Violent Strombolian Activity. Geology, 38, 439-442.

[28] Horwell, C.J., Fenoglio, I., Vala Ragnarsdottir, K., Sparks, R.S.J. and Fubini, B. (2003) Surface Reactivity of Volcanic Ash from the Eruption of Soufrière Hills Volcano, Montserrat, West Indies with Implications for Health Hazards. Environmental Research, 93, 202-215. http://dx.doi.org/10.1016/S0013-9351(03)00044-6

[29] Delmelle, P., Lambert, M., Dufrene, Y., Gerin, P. and Oskarsson, N. (2007) Gas/Aerosol-Ash Interaction in Volcanic Plumes: New Insights from Surface Analyses of Fine Ash Particles. Earth and Planetary Science Letters, 259, 159-170. http://dx.doi.org/10.1016/j.epsl.2007.04.052

[30] Witham, C.S., Oppenheimer, C. and Horwell, C.J. (2005) Volcanic Ash-Leachates: A Review and Recommendations for Sampling Methods. Journal of Volcanology and Geothermal Research, 141, 299-326. http://dx.doi.org/10.1016/j.jvolgeores.2004.11.010

[31] Allard, P., Carbonnelle, J., Metrich, N., Loyer, H. and Zettwoog, P. (1994) Sulphur Output and Magma Degassing Budget of Stromboli Volcano. Nature, 368, 326-330. http://dx.doi.org/10.1038/368326a0

[32] Allard, P., Aiuppa, A., Loyer, H., Carrot, F., Gaudry, A., Pinte, G., Michel, A. and Dongarrà, G. (2000) Acid Gas and Metal Emission Rates during Long-Lived Basalt Degassing at Stromboli Volcano. Journal of Geophysical Research, 27, 1207-1210.

[33] Bertagnini, A., Coltelli, M., Landi, P., Pompilio, M. and Rosi, M. (1999) Violent Explosions Yield New Insights into Dynamics of Stromboli Volcano. Eos, 80, 633-636. http://dx.doi.org/10.1029/99EO00415

[34] Rosi, M., Bertagnini, A., Harris, A.J.L., Pioli, L., Pistolesi, M. and Ripepe, M. (2006) A Case History of Paroxysmal Explosions at Stromboli: Timing and Dynamics of the April 5, 2003 Event. Earth and Planetary Science Letters, 243, 594-606. http://dx.doi.org/10.1016/j.epsl.2006.01.035 
[35] Bertagnini, A., Métrich, N., Francalanci, L., Landi, P., Tommasini, S. and Conticelli, S. (2008) Volcanology and Magma Geochemistry of the Present-Day Activity: Constraints on the Feeding System. In: Calvari, S., Inguaggiato, S., Puglisi, G., Ripepe, M. and Rosi, M., Eds., Learning from Stromboli, American Geophysical Union, Washington, DC, 19-38.

[36] Pasquarè, G., Francalanci, L., Garduno, V.H. and Tibaldi, A. (1993) Structure and Geologic Evolution of the Stromboli Volcano, Aeolian Islands, Italy. Acta Vulcanologica, 3, 79-89.

[37] Tibaldi, A. (2001) Multiple Sector Collapses at Stromboli Volcano, Italy: How They Work. Bulletin of Volcanology, 63, 112-125. http://dx.doi.org/10.1007/s004450100129

[38] Landi, P., Corsaro, R.A., Francalanci, L., Civetta, L., Miraglia, L., Pompilio, M. and Tesoro, R. (2009) Magma Dynamics during the 2007 Stromboli Eruption (Aeolian Islands, Italy). Mineralogy, Geochemistry and Isotope Data. Journal of Volcanology and Geothermal Research, 182, 255-268. http://dx.doi.org/10.1016/j.jvolgeores.2008.11.010

[39] Patrick, M.R., Harris, A.J.L., Ripepe, M., Dehn, J., Rothery, D. and Calvari, S. (2007) Strombolian Explosive Styles and Source Conditions: Insights from Thermal (FLIR) Video. Bulletin of Volcanology, 69, 769-784. http://dx.doi.org/10.1007/s00445-006-0107-0

[40] Walker, G.P.L. (1973) Explosive Volcanic Eruptions-A New Classification Scheme. Geologische Rundschau, 62, 431-446. http://dx.doi.org/10.1007/BF01840108

[41] Blackburn, E.A., Wilson, L. and Sparks, R.S.J. (1976) Mechanisms and Dynamics of Strombolian Activity. Journal of the Geological Society, 132, 429-440. http://dx.doi.org/10.1144/gsjgs.132.4.0429

[42] Self, S., Sparks, R.S.J., Booth, B. and Walker, G.P.L. (1974) The 1973 Heimaey Strombolian Scoria Deposit, Iceland. Geological Magazine, 111, 539-548. http://dx.doi.org/10.1017/S0016756800041583

[43] Ripepe, M., Marchetti, E., Poggi, P., Harris, A.J.L., Fiaschi, A. and Ulivieri, G. (2004) Seismic, Acoustic and Thermal Network Monitors the 2003 Eruption of Stromboli Volcano. Eos, Transactions American Geophysical Union, 85, 329-336. http://dx.doi.org/10.1029/2004EO350001

[44] Andronico, D., Cristaldi, A., Del Carlo, P. and Taddeucci, J. (2009) Shifting Styles of Basaltic Explosive Activity during the 2002-2003 Eruption of Mt. Etna, Italy. Journal of Volcanology and Geothermal Research, 180, 110-122. http://dx.doi.org/10.1016/j.jvolgeores.2008.07.026

[45] Andronico, D., Scollo, S., Cristaldi, A. and Ferrari, F. (2009) Monitoring Ash Emission Episodes at Mt. Etna: The 16 November 2006 Case Study. Journal of Volcanology and Geothermal Research, 180, 123-134. http://dx.doi.org/10.1016/j.jvolgeores.2008.10.019

[46] Taddeucci, J., Spieler, O., Kennedy, B.M., Pompilio, M., Dingwell, D.B. and Scarlato, P. (2004) Experimental and Analytical Modeling of Basaltic Ash Explosions at Mount Etna, Italy, 2001. Journal of Geophysical Research, 109, Article ID: B08203. http://dx.doi.org/10.1029/2003JB002952 
Scientific Research Publishing (SCIRP) is one of the largest Open Access journal publishers. It is currently publishing more than 200 open access, online, peer-reviewed journals covering a wide range of academic disciplines. SCIRP serves the worldwide academic communities and contributes to the progress and application of science with its publication.

Other selected journals from SCIRP are listed as below. Submit your manuscript to us via either submit@scirp.org or Online Submission Portal.
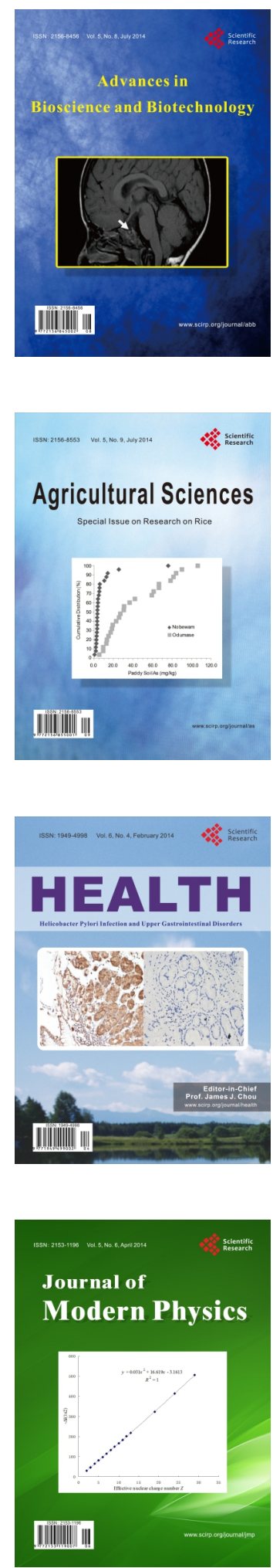
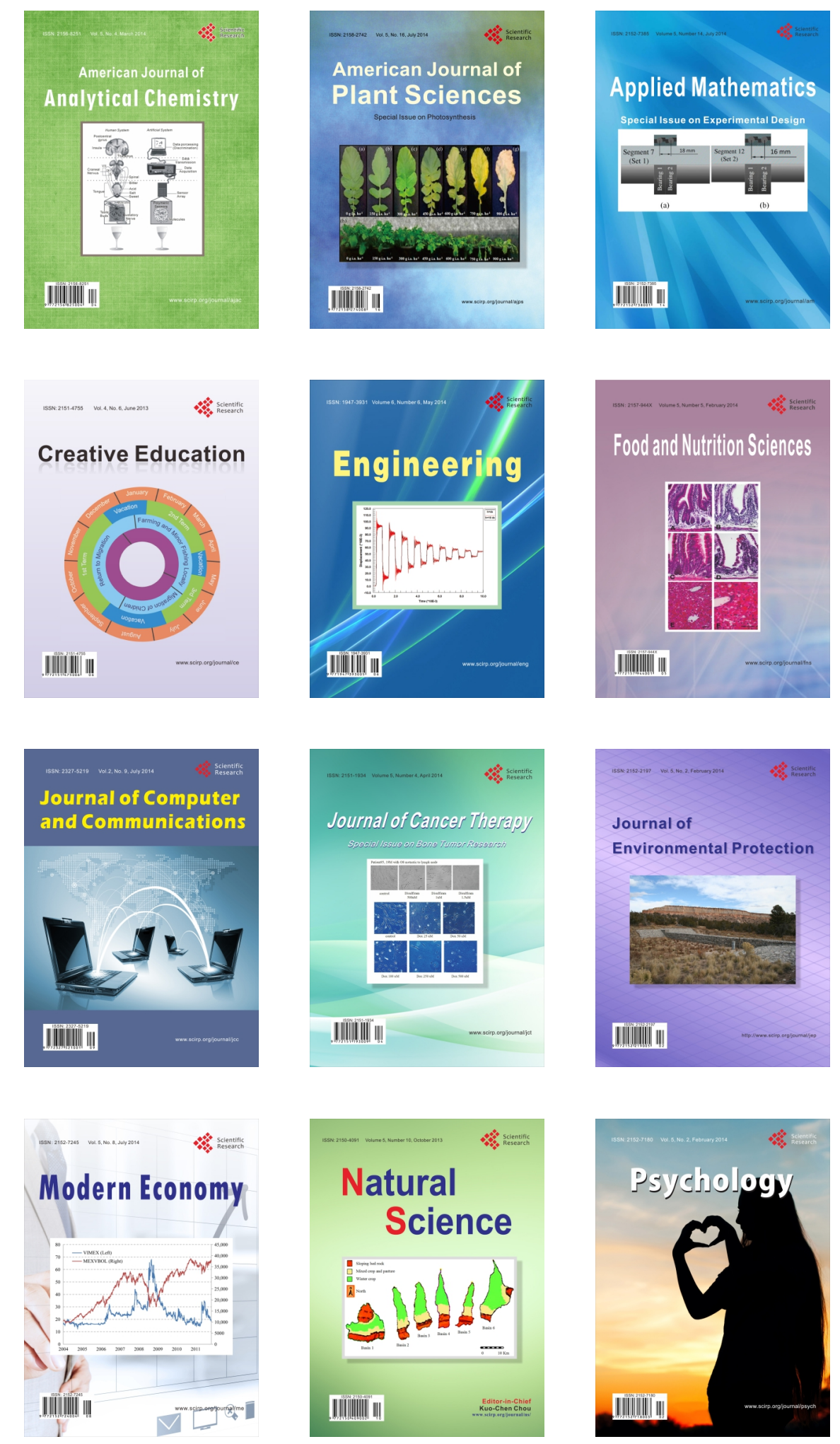